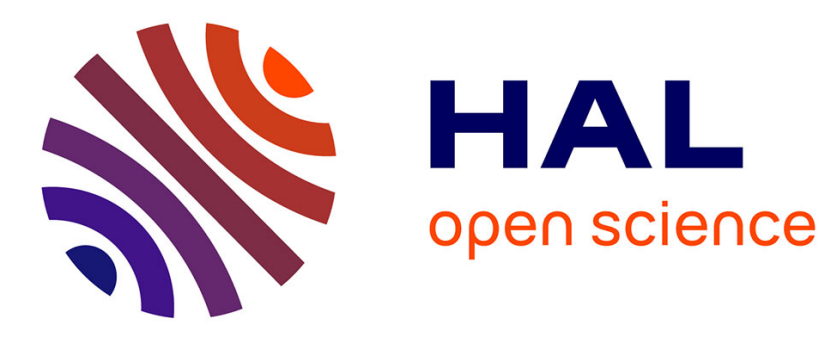

\title{
Transformations of terpenes and terpenoids via carbon-carbon double bond metathesis
}

\author{
Christian Bruneau, Cédric Fischmeister, Dalmo Mandelli, Wagner A. \\ Carvalho, Eduardo N. dos Santos, Pierre H. Dixneuf, Luciana Sarmento \\ Fernandes
}

\section{To cite this version:}

Christian Bruneau, Cédric Fischmeister, Dalmo Mandelli, Wagner A. Carvalho, Eduardo N. dos Santos, et al.. Transformations of terpenes and terpenoids via carbon-carbon double bond metathesis. Catalysis Science \& Technology, 2018, 8 (16), pp.3989-4004. 10.1039/c8cy01152d . hal-01879772

HAL Id: hal-01879772

https://hal-univ-rennes1.archives-ouvertes.fr/hal-01879772

Submitted on 27 Sep 2018

HAL is a multi-disciplinary open access archive for the deposit and dissemination of scientific research documents, whether they are published or not. The documents may come from teaching and research institutions in France or abroad, or from public or private research centers.
L'archive ouverte pluridisciplinaire HAL, est destinée au dépôt et à la diffusion de documents scientifiques de niveau recherche, publiés ou non, émanant des établissements d'enseignement et de recherche français ou étrangers, des laboratoires publics ou privés. 


\title{
Transformations of Terpenes and Terpenoids via Carbon-Carbon Double Bond
}

\section{Metathesis}

\author{
Christian Bruneau, ${ }^{a}{ }^{*}$ Cédric Fischmeister ${ }^{a}$, Dalmo Mandelli ${ }^{b}$, Wagner A. Carvalho ${ }^{b}$, Eduardo N. dos Santos, ${ }^{c}$ Pierre H. Dixneuf ${ }^{a}$ \\ and Luciana Sarmento Fernandes ${ }^{a, b}$
}

\section{Abstract}

Stimulated by the strong interest in replacing fossil raw materials by renewable feedstocks in chemical industry, alkene metathesis of unsaturated biosourced olefins has been recently investigated with the objective of producing high-value molecules using green and atom economic strategies. It is due time to review what has been achieved in this field using terpenes and terpenoids as olefin metathesis partners. These substrates, derived from the isoprene structure, present different types of carbon-carbon double bonds that can be involved in self metathesis, ring closing metathesis, cross metathesis including ethenolysis, and ring opening metathesis. The successful achievements and remaining bottlenecks in this field will be discussed.

\section{Introduction}

Terpenes are found in essential oils and constitute a class of natural products that finds direct applications and serves as feedstocks in flavor and fragrance industry and has other potential applications due to their biological properties. ${ }^{1}$ They are constructed on the basis of connected isoprene units (2-methyl-1,3-butadiene) and thus contain a number of carbon atoms which is a multiple of five. Terpenoids are chemically modified terpenes, essentially oxygenated derivatives such as alcohols, epoxides, ketones, aldehydes, carboxylic acids and esters. Chemical transformations of terpene derivatives have been investigated with the objective of producing new fine chemicals with high added value for diverse applications. Catalytic isomerization, rearrangements, cyclization, ring opening, hydrogenation, dehydrogenation, epoxidation,

a. Univ Rennes, CNRS, ISCR (Institut des Sciences Chimiques de Rennes) - UMR6226, 35000 Rennes, France. E-mail : christian.bruneau@univ-rennes1.fr

${ }^{b}$ Centro de Ciências Naturais e Humanas, Universidade Federal do ABC, Santo

André, Brazil

c. Departamento de Química - ICEx, Universidade Federal de Minas Gerais, Belo Horizonte, Brazil oxidation, hydration, hydroformylation, cyclopropanation are the most studied reactions..$^{2-5}$ Recently, computational studies on metathesis transformations of bulky terpenes such as $\alpha$ - and $\beta$ pinene in ring opening and cross metathesis with various types of catalysts (Ru, Mo, W) have appeared. ${ }^{6,7}$ The scope of this review is the transformation of unsaturated terpenes and terpenoids involving olefin metathesis processes including ring closing metathesis of dienes, cross metathesis with ethylene and functional olefins to produce fine chemicals, and ring opening metathesis as well as ring opening/cross metathesis for the production of polymers. The present review reports on direct transformations of terpenes via double bond metathesis excluding the literature in which terpenes or terpenoids are previously modified to generate a $\mathrm{C}=\mathrm{C}$ double bond suitable for metathesis processes. These transformations of terpenes via alkene metathesis not only add value to renewables but involve green catalytic processes.

\section{Ring closing metathesis (RCM)}

\subsection{Citronellene}

The ring closing metathesis of terpenes has been mainly investigated with citronellene $\mathbf{1}$, linalool $\mathbf{2}$, and myrcene $\mathbf{3}$ (Scheme $1)$. 


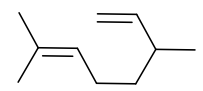

citronellene 1

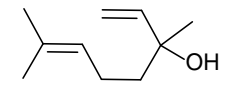

linalool 2

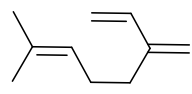

$\beta$-myrcene 3
Scheme 1. Terpenes used in ring closing metathesis

To the best of our knowledge, the first ring closing metathesis of a terpene containing a 1,6-diene system has been carried out with molybdenum and tungsten catalysts. The Schrock catalyst $\mathrm{Mo}\left(=\mathrm{CHC}(\mathrm{Me})_{2} \mathrm{Ph}\right)\left(\left(\mathrm{CF}_{3}\right)_{2} \mathrm{MeCO}\right)_{2}\left(2,6-{ }^{i} \mathrm{Pr}_{2}\left(\mathrm{C}_{6} \mathrm{H}_{3} \mathrm{~N}\right)\right.$ Mo1 catalyzed the ring closing metathesis of technical grade (-)-citronellene on a preparative scale $(50 \mathrm{~g})$ at room temperature in $p$-xylene within $1 \mathrm{~h}$ with a catalyst loading of 0.1 mol\% leading to 3-methylcyclopentene 4 in $60 \%$ isolated yield without isomerization (Scheme 2). ${ }^{8}$ Full conversion was obtained in $30 \mathrm{~min}$ when 2 mol\% of catalyst was used and it was noted that no epimerization took place at low substrate concentration (0.75 M). By contrast, at higher concentration (50 wt\%) a mixture of methylcyclopentene isomers was produced. In the presence of 2 mol\% of $\mathrm{WOCl}_{2}\left(2,6-\mathrm{Br}_{2} \mathrm{C}_{6} \mathrm{H}_{3} \mathrm{O}\right)_{2} \mathbf{W} \mathbf{1}$ as catalyst, each optically pure $(R)$ - and $(S)$-citronellene enantiomer was converted at $90{ }^{\circ} \mathrm{C}$ in 1,2,5-trichlorobenzene for $1 \mathrm{~h}$ into the corresponding 3-methylcyclopentene (R)-4 and (S)-4 in $68-70 \%$ isolated yield and $97 \%$ enantiomeric excess with retention of configuration (Scheme 2). ${ }^{9}$<smiles>C=CC(C)CCC=C(C)C</smiles><smiles>CCCc1cccc(PCC)c1N=CC(C)(C)c1ccccc1</smiles>

Mo1

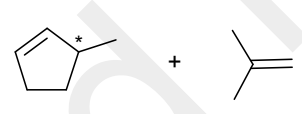

4
Mo1 (2 mol\%) p-xylene

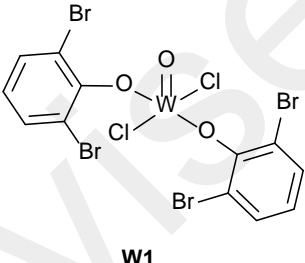
$25{ }^{\circ} \mathrm{C}, 30 \mathrm{~min}$

W1 $(2 \mathrm{~mol} \%)$ 1,2,4-trichlorobenzene $90{ }^{\circ} \mathrm{C}, 1 \mathrm{~h}$

W1

Scheme 2 Ring closing metathesis of citronellene 1 with molybdenum and tungsten catalysts

Later on, the same RCM reaction was achieved with full conversion of $(R)$-citronellene $\mathbf{1}$ with 0.5 mol\% of the ruthenium catalyst Ru1 (Scheme 3 ) in toluene at $80{ }^{\circ} \mathrm{C}$ using microwave heating during 20 $\min ^{10}$

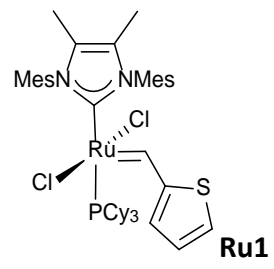

Scheme 3 Structure of complex Ru1

Immobilization of classical Hoveyda type catalysts derived from Ru6 $6^{11}$ on silica and mesoporous molecular sieves was detrimental for the RCM of citronellene. ${ }^{11 a}$ Other Hoveyda type ruthenium catalysts bearing a quaternary ammonium group linked to their $N$-heterocyclic carbene ligand such as Ru2 (Scheme 4) have been immobilized on silica (SBA-15) and their catalytic activity has been evaluated in different metathesis transformations including RCM of citronellene. $^{11 b}$

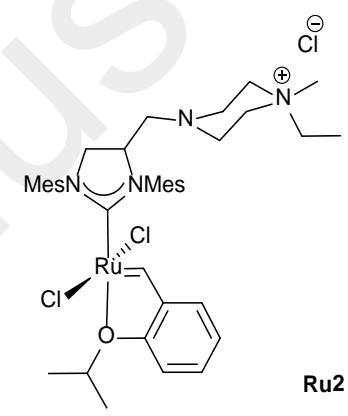

Scheme 4 Structure of complex Ru2

A conversion of $93 \%$ was obtained when the reaction was catalyzed by 84 ppm of immobilized catalyst with a substrate/catalyst ratio of 12000 in toluene at $60{ }^{\circ} \mathrm{C}$ for $6 \mathrm{~h}$. At $80{ }^{\circ} \mathrm{C}$, a TON of 16000 was reached with very high conversion, and most importantly no formation of byproduct was observed and the catalyst could be recycled. It is noteworthy that the reaction carried out without solvent also gave full conversion of $\mathbf{1}$ but only $30 \%$ of $\mathbf{4}$ was formed together with considerable amounts of the self metathesis product and oligomers as well as cycloisomerization products (Scheme 5). 


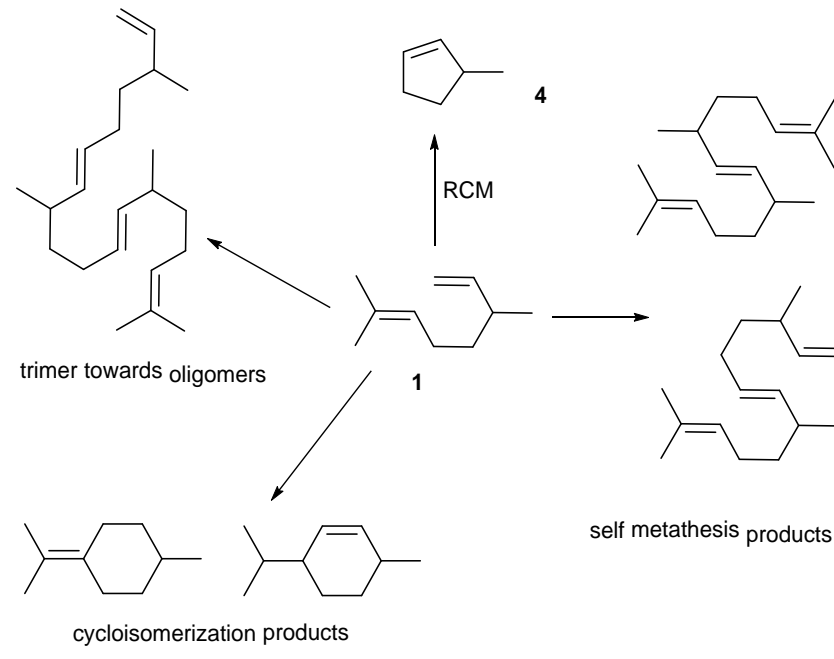

Scheme 5. Various metathesis and cycloisomerization products formed under neat conditions with SBA15 supported Ru2

\subsection{Linalool}

Linalool $\mathbf{2}$ is the monoterpene derivative that has been most often used in test reaction to evaluate the catalytic properties of new ruthenium catalysts. Its ring closing metathesis reaction leads to 2-methylprop-1-ene 5 and 1-methylcyclopent-2-en-1-ol 6 as primary products.

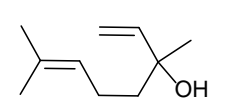

2
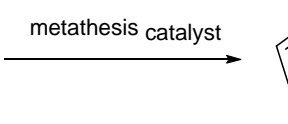

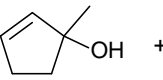

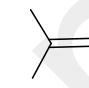

Scheme 6 Ring closing metathesis of linalool 2

The ruthenium catalysts that have been used for this RCM reaction are presented in Scheme 8. Initial studies carried out with 4-10 mol\% of the first generation Grubbs catalyst Ru3 at room temperature in $\mathrm{CDCl}_{3}$ showed that the presence of the allylic alcohol group in linalool had a beneficial effect on the rate of the metathesis reaction as compared to citronellene $1 .^{12}$ Under similar conditions, the reactivity of linalool $\mathbf{2}$ was one order of magnitude higher than that of the diene 1 , whereas the $O$-methoxy-protected linalool presented no reactivity even at $65^{\circ} \mathrm{C}$. This enhancement of reactivity was attributed to the acceleration of the rate of carbene exchange between the terminal vinyl group and the ruthenium alkylidene species due to interaction of the alcohol with the catalytic species through chloride or phosphine substitution favouring pre-association of the substrate with the catalytic metal carbene.
The activity of Ru3 was confirmed in chloroform at room temperature and full conversion of $\mathbf{2}$ into $\mathbf{6}$ was observed within 60 min at room temperature. The second generation Grubbs catalyst Ru4 also gave full conversion whereas the Hoveyda-Grubbs catalysts Ru5 and Ru6 exhibited a slightly lower activity (Table 1 entries 1-4). ${ }^{13}$ Other second generation ruthenium complexes (Ru7, Ru8 and Ru9), equipped with a very bulky $\mathrm{N}$-heterocyclic carbene ligand containing substituted naphthyl groups were found to be very efficient for the ring closing metathesis of linalool. Full conversion with excellent yields of isolated 1-methylcyclopent-2-en1-ol 6 were obtained in 6-30 $\mathrm{min}$ in dichloromethane at room temperature with 1 mol\% of catalyst (Table 1 - entries 5-7). ${ }^{14}$ Ru1 (Scheme 3) has been used with a low catalyst loading of $0.1 \mathrm{~mol} \%$ at $80{ }^{\circ} \mathrm{C}$ in toluene and dimethylcarbonate (DMC) but after one hour, the conversion of 2 reached $40-43 \%$ only (Table 1 - entries 8,9 ). ${ }^{10} \mathrm{~A}$ higher conversion of $70 \%$ was obtained when the reaction was performed under neat conditions but undesired oligomer formation was observed. It was however possible to reach full conversion within 10 min by increasing the catalyst loading to from 0.1 to 0.5 mol\%. The authors confirmed that the presence of the allylic alcohol functionality increased the reaction rate since the full conversion of citronellene under similar conditions required a twice longer time of $20 \mathrm{~min}$. This ring closing metathesis could be scaledup using microwave heating and continuous flow process. ${ }^{10}$ The RCM of linalool has been investigated with Grubbs (Ru11, Ru12) and Hoveyda (Ru14, Ru15) second generation catalysts featuring frozen saturated $\mathrm{N}$-heterocyclic imidazolinylidene ligands substituted on the backbone of the five-membered ring by two phenyl groups in syn-position and by ortho-tolyl groups at the nitrogen atoms with a syn or anti-conformation. ${ }^{15}$ Full conversions of linalool were obtained within 7 and $10 \mathrm{~min}$ when the reactions were achieved in dichloromethane at $30{ }^{\circ} \mathrm{C}$ with $1 \mathrm{~mol} \%$ of the Grubbs type catalysts Ru11 and Ru12, respectively. The less sterically hindered catalyst Ru10 was also efficient and led to full conversion in $13 \mathrm{~min}$ (Table 1-entries 11-13). With a low catalyst loading of $0.1 \mathrm{~mol} \%$, conversions were incomplete and a higher catalytic activity of the syn-isomer Ru11 was observed with a maximum conversion reaching 59\% after one hour (Table 1 - entries 14-16). ${ }^{15}$ The RCM reactions with the Hoveyda type catalysts Ru14 and Ru15 were carried out at $60{ }^{\circ} \mathrm{C}$ in deuterated benzene. In the presence of $1 \mathrm{~mol} \%$ of catalyst, full conversion was rapidly reached within 6 min with Ru14, Ru15 and the analog Ru13. With a lower 
catalyst loading of $0.1 \mathrm{~mol} \%$, full conversion were also obtained with Ru13 and Ru14 in one hour at $60{ }^{\circ} \mathrm{C}$, whereas the anti-isomer Ru15 was less efficient giving only $90 \%$ conversion after the same reaction time (Table 1 - entries 17-22).

With catalysts Ru10, Ru11 and Ru12, it was observed that after formation of 1-methylcyclopent-2-en-1-ol 6, complete dehydration of the alcohol took place to give first 2-methylcyclopentadiene (2-MCPD) 7 within $2 \mathrm{~h}$, and then a mixture with its isomer 1-methylcyclopentadiene (1-MCPD) 8 (Scheme 7). With the phosphine-free Hoveyda type catalysts Ru13-Ru15, these subsequent reactions taking place after formation of $\mathbf{6}$ were much less efficient.

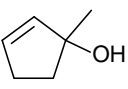

6

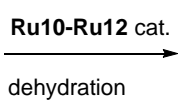

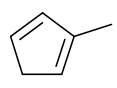

2-MCPD 7

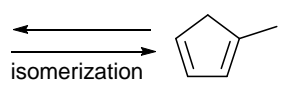

1-MCPD 8
Scheme 7 Dehydration of 1-methylcyclopent-2-en-1-ol 6 catalyzed by Grubbs type catalyst

The commercially available catalysts Ru3, Ru6 and Ru10 were used to evaluate the RCM of linalool without solvent (Table 1, entries 2326). ${ }^{16}$ The second generation Hoveyda type complex Ru6 appeared to be the best catalyst making the full conversion of $\mathbf{2}$ possible at room temperature with a catalyst loading of 0.1 mol\% (Table 1 entry 23). The Grubbs type catalysts Ru3 and Ru10 were less efficient under neat conditions even at higher temperature. In this case also, dehydration of 1-methylcyclopent-2-en-1-ol 6 to methylcyclopentadienes was observed with Ru3 and Ru6 when the temperature was increased to $60^{\circ} \mathrm{C}$. The dehydration process was attributed to the release of a catalytic amount of $\mathrm{HCl}$ resulting from decomposition of the ruthenium catalyst, which is able to initiate the acid-catalyzed dehydration of cyclic alcohols. ${ }^{17}$

Ruthenium complexes Ru18-Ru20 equipped with a benzylidene and a pyridine ligand with at least one chloride atom substituted by an alkoxide have been prepared and evaluated in ring closing metathesis of dienes. ${ }^{18}$ In the presence of 0.05 mol\% of catalyst in refluxing $\mathrm{CDCl}_{3}$, linalool was converted into 1-methylcyclopent-2en-1-ol 6. Ru20 featuring two pentafluorophenoxy ligands exhibited an exceptional activity leading to full conversion in 1 hour, whereas the other catalyst precursors showed conversions located in the range 17-34\% (Table 1 - entries 27-31). Nevertheless, all these ruthenium-pseudohalide catalysts led to $100 \%$ conversion in 15 min when the catalyst loading was as low as 0.5 mol\%. ${ }^{18}$
The benzylidene complex Ru21 containing a tridentate phosphinesulfonate has shown a modest activity for the RCM of linalool 2 with $35 \%$ yield of 6 after $20 \mathrm{~h}$ in refluxing $\mathrm{CDCl}_{3}$ with a catalyst loading of 1 mol\% (Table 1 - entry 32). ${ }^{19}$

Schiff bases derived from salicylaldehyde were coordinated to mononuclear (Ru22-Ru27) and homobimetallic (Ru28-Ru33) ruthenium benzylidene complexes. ${ }^{20}$ Ring closing metathesis of linalool $\mathbf{2}$ was attempted with these two series of complexes with a catalyst loading of 5 mol\% in $\mathrm{C}_{6} \mathrm{D}_{5} \mathrm{Cl}$ at $70{ }^{\circ} \mathrm{C}$ for the mononuclear and at $55{ }^{\circ} \mathrm{C}$ for the binuclear catalysts. In a general manner, the binuclear were more active than the mononuclear complexes equipped with the same Schiff base ligand as after $4 \mathrm{~h}$ the reactions carried out at $55^{\circ} \mathrm{C}$ with Ru28-Ru33 (Table 1 - entries 39-44) gave better yields of 6 than Ru23-Ru27 (Table 1 - entries 33-38) at $70{ }^{\circ} \mathrm{C}$. Even though some differences were also observed related to the nature of the Schiff base ligand, these complexes showed moderate catalytic activities.

It has been shown that ruthenium vinylidene complexes were efficient catalyst precursors for olefin metathesis. ${ }^{21}$ Ruthenium vinylidene complexes (Ru34-Ru36) analogs of second generation Grubbs catalysts Ru4, and ruthenium vinylidene complexes with a Schiff base as ligand (Ru37-Ru42) were prepared and used for ring closing metathesis of linalool. $^{22}$ Catalyst Ru34-Ru36 led to satisfactory yields of 1-methylcyclopent-2-en-1-ol 6 in $2 \mathrm{~h}$ at $60^{\circ} \mathrm{C}$ in $\mathrm{C}_{6} \mathrm{D}_{6}$ with a catalyst loading of 5 mol\% (Table 1 - entries $45-47$ ). On the other hand, complexes Ru37-Ru42 were much less active and required $24 \mathrm{~h}$ at $80{ }^{\circ} \mathrm{C}$ to reach the same level of conversion (Table 1- entries 48-53). The ring closing metathesis of linalool has also been attempted with catalysts generated in situ from a ruthenium complex in the presence of trimethylsilyldiazomethane as carbene precursor according to an established methodology. ${ }^{23}$ The Schiff base complexes Ru43-Ru45 activated by 2.2 equivalents of TMSD at $70{ }^{\circ} \mathrm{C}$ in toluene for $1 \mathrm{~h}$ led to modest yields of 6 (Table 1 - entries 54-56). ${ }^{24}$ Even though it is difficult to compare all the results of Table 1, which have been obtained under different experimental conditions, it appears that the best ruthenium catalysts for the ring closing metathesis of linalool are second generation Grubbs and Hoveyda catalysts equipped with a bulky $N$-heterocyclic carbene ligand. It is noteworthy that the complex Ru20 containing two aryloxy ligands instead of chlorides and an unsaturated NHC ligand was very active at $60^{\circ} \mathrm{C}$ with a low catalyst loading of $0.05 \mathrm{~mol} \%$. 


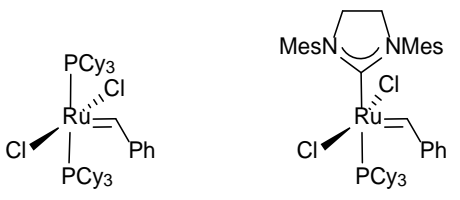

Ru3<smiles>ClC(=[Te]=C[R](Cl)(Cl)C1=NCCN1)c1ccccc1</smiles>

$\operatorname{Ar}=\operatorname{Ar}_{1}(\mathbf{R u 7}), \operatorname{Ar}_{2}$ (Ru8), $\operatorname{Ar}_{3}$ (Ru9)<smiles></smiles>

Ru10

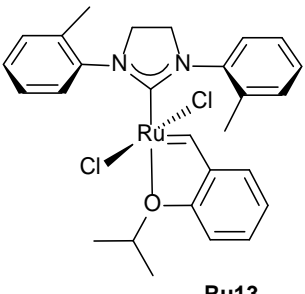

Ru13
Ru4

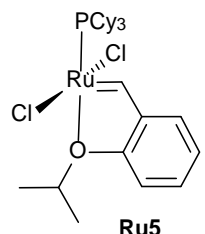

Ru5

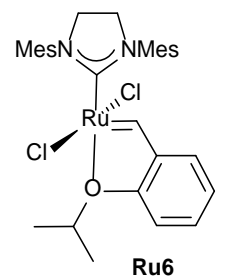

$\mathrm{Ar}_{2}=$<smiles>CC(C)c1ccc2ccc(C(C)C)cc2c1</smiles>

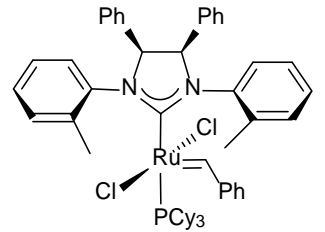

Ru11

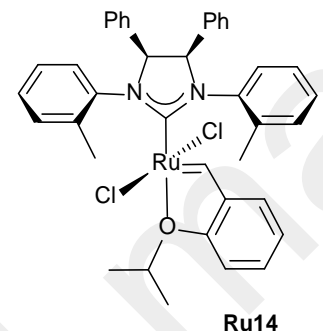

Ru14

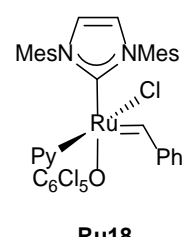

Ru18

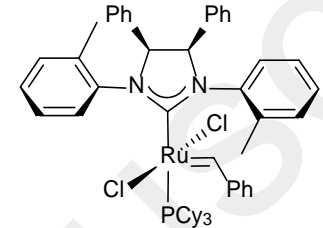

Ru12

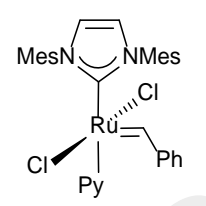

Ru16

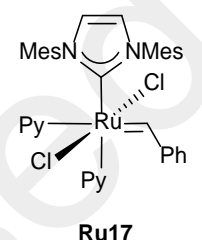

Ru17

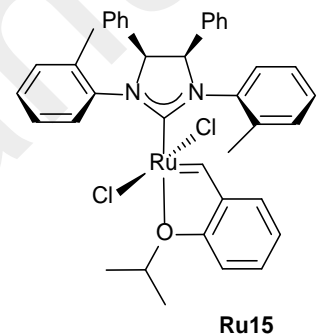

Ru15

Scheme 8. Selected ruthenium catalysts used for terpene metathesis transformations 

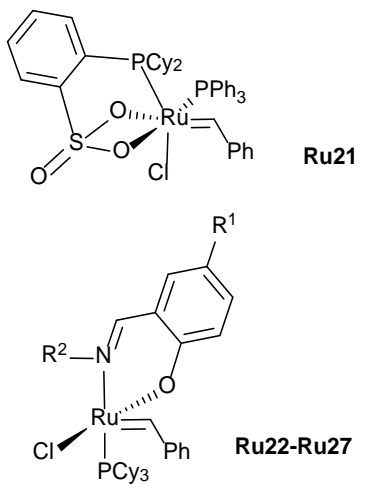

$\mathrm{R}^{1}=\mathrm{H}, \mathrm{R}^{2}=\mathrm{Me}, \mathbf{R u 2 2}$ $\mathrm{R}^{1}=\mathrm{NO}_{2}, \mathrm{R}^{2}=\mathrm{Me}, \mathbf{R u} 23$

$\mathrm{R}^{1}=\mathrm{H}, \mathrm{R}^{2}=2,6-\mathrm{Me}_{2}-4-\mathrm{BrC}_{6} \mathrm{H}_{2}, \mathbf{R u} 24$ $\mathrm{R}^{1}=\mathrm{NO}_{2}, \mathrm{R}^{2}=2,6-\mathrm{Me}_{2}-4-\mathrm{BrC}_{6} \mathrm{H}_{2}$, Ru25 $\mathrm{R}^{1=} \mathrm{H}, \mathrm{R}^{2}=2,6-{ }^{i} \mathrm{Pr}_{2} \mathrm{C}_{6} \mathrm{H}_{3}, \mathbf{R u} 26$

$\mathrm{R}^{1}=\mathrm{NO}_{2}, \mathrm{R}^{2}=2,6-{ }_{-} \mathrm{Pr}_{2} \mathrm{C}_{6} \mathrm{H}_{3}, \mathbf{R u} 27$<smiles>[R]C=C(Cl)[Ge](Cl)(Cl)C1=NCCN1C</smiles>

$\mathrm{R}=\mathrm{Ph}, \mathbf{R u} 34$

$\mathrm{SiMe}_{3}, \mathbf{R u} 35$

${ }^{t} \mathrm{Bu}, \mathbf{R u} 36$

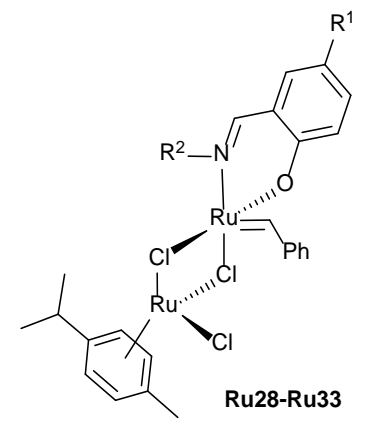

$\mathrm{R}^{1}=\mathrm{H}, \mathrm{R}^{2}=\mathrm{Me}, \mathbf{R u 2 8}$

$\mathrm{R}^{1}=\mathrm{NO}_{2}, \mathrm{R}^{2}=\mathrm{Me}, \mathbf{R u} 29$

$\mathrm{R}^{1}=\mathrm{H}, \mathrm{R}^{2}=2,6-\mathrm{Me}_{2}-4-\mathrm{BrC}_{6} \mathrm{H}_{2}, \mathbf{R u} 30$

$\mathrm{R}^{1}=\mathrm{NO}_{2}, \mathrm{R}^{2}=2,6-\mathrm{Me}_{2}-4-\mathrm{BrC}_{6} \mathrm{H}_{2}, \mathrm{Ru} 31$

$\mathrm{R}^{1}=\mathrm{H}, \mathrm{R}^{2}=2,6-{ }^{i} \mathrm{Pr}_{2} \mathrm{C}_{6} \mathrm{H}_{3}, \mathbf{R u} 32$

$\mathrm{R}^{1}=\mathrm{NO}_{2}, \mathrm{R}^{2}=2,6-{ }^{-} \mathrm{Pr}_{2} \mathrm{C}_{6} \mathrm{H}_{3}$, Ru33

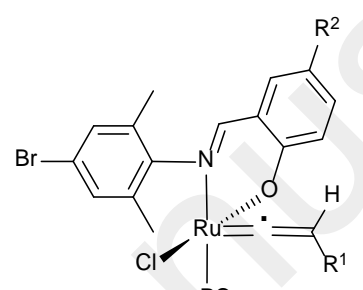

$\mathrm{PCy}_{3}$

$\mathrm{R}^{1=} \mathrm{Ph}, \mathrm{R}^{2}=\mathrm{H}, \mathrm{Ru} 37 \quad \mathrm{R}^{1}=\mathrm{SiMe}_{3}, \mathrm{R}^{2}=\mathrm{NO}_{2}, \mathbf{R u} 40$

$\mathrm{R}^{1}=\mathrm{Ph}, \mathrm{R}^{2}=\mathrm{NO}_{2}, \mathbf{R u 3 8} \quad \mathrm{R}^{1}={ }_{\mathrm{Bu}} \mathrm{R}^{2}=\mathrm{H}, \mathbf{R u} 41$

$\mathrm{R}^{1=} \mathrm{SiMe}_{3}, \mathrm{R}^{2}=\mathrm{H}, \mathbf{R u} 39 \quad \mathrm{R}^{1}={ }_{\mathrm{Bu}}, \mathrm{R}^{2}=\mathrm{NO}_{2}, \mathbf{R u} 42$

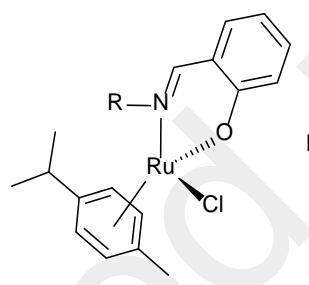

$\mathrm{R}=\mathrm{Me}, \mathrm{Ru} 43,{ }^{\mathrm{t}} \mathrm{Bu}, \mathbf{R u} 44$,

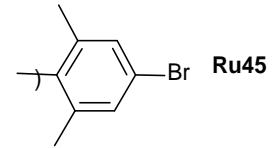

Scheme 8 (continued). Selected ruthenium catalysts used for terpene metathesis transformations

Table 1. Ring closing metathesis of linalool

\begin{tabular}{cccccccc}
\hline Entry & Catalyst & $\begin{array}{c}\text { Cat. loading } \\
(\text { mol\%) }\end{array}$ & Solvent & Temperature $\left({ }^{\circ} \mathrm{C}\right)$ & Time $(\mathrm{min})$ & $\begin{array}{c}\text { Conversion or } \\
\text { yield* }(\%)\end{array}$ & Ref \\
\hline 1 & Ru3 & 5 & $\mathrm{CDCl}_{3}$ & $\mathrm{rt}$ & 60 & 100 & 13 \\
2 & Ru4 & 5 & $\mathrm{CDCl}_{3}$ & $\mathrm{rt}$ & 60 & 100 & 13
\end{tabular}




\begin{tabular}{|c|c|c|c|c|c|c|c|}
\hline 3 & Ru5 & 5 & $\mathrm{CDCl}_{3}$ & $\mathrm{rt}$ & 60 & 65 & 13 \\
\hline 4 & Ru6 & 5 & $\mathrm{CDCl}_{3}$ & $\mathrm{rt}$ & 60 & 95 & 13 \\
\hline 5 & Ru7 & 1 & $\mathrm{CH}_{2} \mathrm{Cl}_{2}$ & $\mathrm{rt}$ & 30 & $92^{*}$ & 14 \\
\hline 6 & Ru8 & 1 & $\mathrm{CH}_{2} \mathrm{Cl}_{2}$ & $\mathrm{rt}$ & 6 & $88^{*}$ & 14 \\
\hline 7 & Ru9 & 1 & $\mathrm{CH}_{2} \mathrm{Cl}_{2}$ & $\mathrm{rt}$ & 6 & $94 *$ & 14 \\
\hline 8 & Ru1 & 0.1 & toluene & 80 & 60 & 43 & 10 \\
\hline 9 & Ru1 & 0.1 & DMC & 80 & 60 & 40 & 10 \\
\hline 10 & Ru1 & 0.5 & toluene & 80 & 10 & 100 & 10 \\
\hline 11 & Ru10 & 1 & $\mathrm{CD}_{2} \mathrm{Cl}_{2}$ & 30 & 13 & 100 & 15 \\
\hline 12 & Ru11 & 1 & $\mathrm{CD}_{2} \mathrm{Cl}_{2}$ & 30 & 7 & 100 & 15 \\
\hline 13 & Ru12 & 1 & $\mathrm{CD}_{2} \mathrm{Cl}_{2}$ & 30 & 10 & 100 & 15 \\
\hline 14 & Ru10 & 0.1 & $\mathrm{CD}_{2} \mathrm{Cl}_{2}$ & 30 & 60 & 30 & 15 \\
\hline 15 & Ru11 & 0.1 & $\mathrm{CD}_{2} \mathrm{Cl}_{2}$ & 30 & 60 & 59 & 15 \\
\hline 16 & Ru12 & 0.1 & $\mathrm{CD}_{2} \mathrm{Cl}_{2}$ & 30 & 60 & 33 & 15 \\
\hline 17 & Ru13 & 1 & $\mathrm{C}_{6} \mathrm{D}_{6}$ & 60 & 6 & 100 & 15 \\
\hline 18 & Ru14 & 1 & $\mathrm{C}_{6} \mathrm{D}_{6}$ & 60 & 6 & 100 & 15 \\
\hline 19 & Ru15 & 1 & $\mathrm{C}_{6} \mathrm{D}_{6}$ & 60 & 6 & 100 & 15 \\
\hline 20 & Ru13 & 0.1 & $\mathrm{C}_{6} \mathrm{D}_{6}$ & 60 & 6 & $>98$ & 15 \\
\hline 21 & Ru14 & 0.1 & $\mathrm{C}_{6} \mathrm{D}_{6}$ & 60 & 6 & $>98$ & 15 \\
\hline 22 & Ru15 & 0.1 & $\mathrm{C}_{6} \mathrm{D}_{6}$ & 60 & 6 & 90 & 15 \\
\hline 23 & Ru6 & 0.1 & neat & $\mathrm{rt}$ & 45 & 100 & 16 \\
\hline 24 & Ru6 & 0.01 & neat & $\mathrm{rt}$ & 60 & 44 & 16 \\
\hline 25 & Ru10 & 0.1 & neat & 60 & 30 & 36 & 16 \\
\hline 26 & Ru3 & 0.1 & neat & 45 & 60 & 55 & 16 \\
\hline 27 & Ru16 & 0.05 & $\mathrm{CDCl}_{3}$ & reflux & 60 & 24 & 18 \\
\hline 28 & Ru17 & 0.05 & $\mathrm{CDCl}_{3}$ & reflux & 60 & 29 & 18 \\
\hline 29 & Ru18 & 0.05 & $\mathrm{CDCl}_{3}$ & reflux & 60 & 17 & 18 \\
\hline 30 & Ru19 & 0.05 & $\mathrm{CDCl}_{3}$ & reflux & 60 & 34 & 18 \\
\hline 31 & Ru20 & 0.05 & $\mathrm{CDCl}_{3}$ & reflux & 60 & 100 & 18 \\
\hline 32 & Ru21 & 1 & $\mathrm{CDCl}_{3}$ & reflux & 1200 & 35 & 19 \\
\hline 33 & Ru22 & 5 & $\mathrm{C}_{6} \mathrm{D}_{5} \mathrm{Cl}$ & 70 & 240 & 12 & 20 \\
\hline 34 & Ru23 & 5 & $\mathrm{C}_{6} \mathrm{D}_{5} \mathrm{Cl}$ & 70 & 240 & 13 & 20 \\
\hline 35 & Ru24 & 5 & $\mathrm{C}_{6} \mathrm{D}_{5} \mathrm{Cl}$ & 70 & 240 & 18 & 20 \\
\hline 36 & Ru25 & 5 & $\mathrm{C}_{6} \mathrm{D}_{5} \mathrm{Cl}$ & 70 & 240 & 25 & 20 \\
\hline 37 & Ru26 & 5 & $\mathrm{C}_{6} \mathrm{D}_{5} \mathrm{Cl}$ & 70 & 240 & 41 & 20 \\
\hline 38 & Ru27 & 5 & $\mathrm{C}_{6} \mathrm{D}_{5} \mathrm{Cl}$ & 70 & 240 & 56 & 20 \\
\hline 39 & Ru28 & 5 & $\mathrm{C}_{6} \mathrm{D}_{5} \mathrm{Cl}$ & 55 & 240 & 32 & 20 \\
\hline 40 & Ru29 & 5 & $\mathrm{C}_{6} \mathrm{D}_{5} \mathrm{Cl}$ & 55 & 240 & 25 & 20 \\
\hline 41 & Ru30 & 5 & $\mathrm{C}_{6} \mathrm{D}_{5} \mathrm{Cl}$ & 55 & 240 & 69 & 20 \\
\hline 42 & Ru31 & 5 & $\mathrm{C}_{6} \mathrm{D}_{5} \mathrm{Cl}$ & 55 & 240 & 66 & 20 \\
\hline 43 & Ru32 & 5 & $\mathrm{C}_{6} \mathrm{D}_{5} \mathrm{Cl}$ & 55 & 240 & 87 & 20 \\
\hline 44 & Ru33 & 5 & $\mathrm{C}_{6} \mathrm{D}_{5} \mathrm{Cl}$ & 55 & 240 & 74 & 20 \\
\hline 45 & Ru34 & 5 & $\mathrm{C}_{6} \mathrm{D}_{6}$ & 60 & 120 & 69 & 22 \\
\hline 46 & Ru35 & 5 & $\mathrm{C}_{6} \mathrm{D}_{6}$ & 60 & 120 & 89 & 22 \\
\hline 47 & Ru36 & 5 & $\mathrm{C}_{6} \mathrm{D}_{6}$ & 60 & 120 & 80 & 22 \\
\hline 48 & Ru37 & 5 & $\mathrm{C}_{6} \mathrm{D}_{6}$ & 80 & 1440 & 27 & 22 \\
\hline 49 & Ru38 & 5 & $\mathrm{C}_{6} \mathrm{D}_{6}$ & 80 & 1440 & 54 & 22 \\
\hline 50 & Ru39 & 5 & $C_{6} D_{6}$ & 80 & 1440 & 70 & 22 \\
\hline 51 & Ru40 & 5 & $\mathrm{C}_{6} \mathrm{D}_{6}$ & 80 & 1440 & 81 & 22 \\
\hline 52 & Ru41 & 5 & $C_{6} D_{6}$ & 80 & 1440 & 68 & 22 \\
\hline 53 & Ru42 & 5 & $\mathrm{C}_{6} \mathrm{D}_{6}$ & 80 & 1440 & 75 & 22 \\
\hline 54 & Ru43 & $5+$ TMSD & toluene & 70 & 60 & 16 & 24 \\
\hline 55 & Ru44 & $5+$ TMSD & toluene & 70 & 60 & 21 & 24 \\
\hline 56 & Ru45 & $5+$ TMSD & toluene & 70 & 60 & 28 & 24 \\
\hline
\end{tabular}

The ring closing metathesis of $\beta$-myrcene 3 was first achieved with the second generation Grubbs catalyst Ru4 at $40{ }^{\circ} \mathrm{C}$ in decaline as solvent (Scheme 9). ${ }^{25}$ 


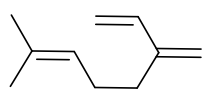

3

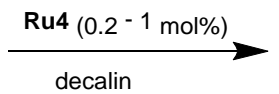

$40{ }^{\circ} \mathrm{C}, 5 \mathrm{~h}$

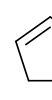

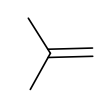

5
Scheme 9 Ring closing metathesis of $\beta$-myrcene 3 into 3-methylenecyclopentene 9

From this triene, a conversion of $68 \%$ and an isolated yield of $45 \%$ of 3-methylenecyclopentene 9 were obtained after $5 \mathrm{~h}$ with a catalyst loading of 0.2 mol\%, but full conversion was achieved in the presence of 1 mol\% of catalyst. The diene $\mathbf{9}$ was then used for controlled cationic polymerization with a catalytic system based on ${ }^{i} \mathrm{BuOCH}(\mathrm{Cl}) \mathrm{Me} / \mathrm{ZnCl}_{2} / \mathrm{Et}_{2} \mathrm{O}$ in toluene.

Later, it was shown that even in the presence of methyl acrylate as cross metathesis partner, the ring closing metathesis of $\beta$-myrcene was favoured over the direct cross metathesis reaction. ${ }^{26}$ The first generation Grubbs catalyst Ru3 was almost inactive for this transformation. Only second generation benzylidene and indenylidene ruthenium catalysts such as Ru4 and Ru46 were efficient, leading to almost full conversion of $\beta$-myrcene at $80^{\circ} \mathrm{C}$ in the presence of $0.5 \mathrm{~mol} \%$ of catalyst within $1 \mathrm{~h}$ with production of 9 in $62-67 \%$ GC yields and the cross metathesis product 10 in 13-14\% (Scheme 10). A low amount of catalyst (0.25 mol\%) favoured the formation of 9 (54\%) but the conversion of 3 was lower (64\%). Increasing the catalyst loading somehow increased the production of $\mathbf{1 0}$ but at the same time led to polymers upon consumption of $\mathbf{2}$ via ring opening. When the ratio $\beta$-myrcene $\mathbf{3}$ /acrylate $\mathbf{1 1}$ was varied from $1: 2$ to $1: 16$, the ratio of $\mathbf{9}$ to 10 decreased from 5:74 to 20:47 with an overall full conversion of 3 , but when the proportion of acrylate 11 became too important, products resulting from its self metathesis appeared. Up to $0.5 \mathrm{~mol}^{-1}$ concentration of $\beta$ myrcene, no significant effects on reactivity and selectivity were observed, but above this value a drop of the conversion attributed to catalyst inhibition was noted.

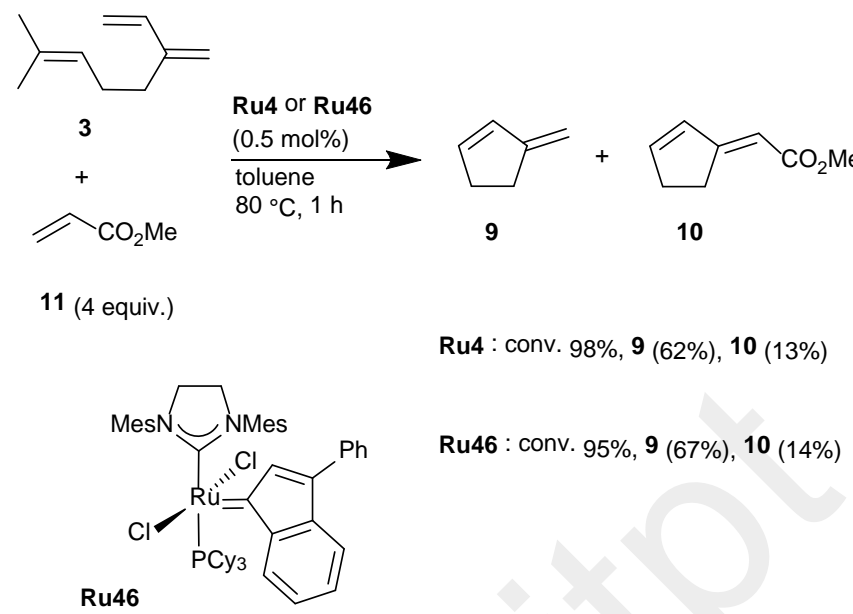

Scheme 10 Ring closing metathesis of $\beta$-myrcene 3 in the presence of methyl acrylate $\mathbf{1 1}$

The RCM of the isomers of $\beta$-myrcene, cis- and trans- $\beta$-ocimene 12 and 13 in a respective 33:67 ratio (Scheme 11) was then studied in the presence of catalyst Ru46. The cis-derivative $\mathbf{1 2}$ was very reactive and led to $94 \%$ conversion after $1 \mathrm{~h}$ at $80{ }^{\circ} \mathrm{C}$, whereas only $33 \%$ of the trans-isomer $\mathbf{1 3}$ was converted under the same conditions. However, the yield of the expected 2-methylcyclopentadiene 7 was only $24 \%$ indicating that side or subsequent reactions took place.

As compared to $\beta$-myrcene, which contains two terminal double bonds, the $\beta$-ocimene isomers present only one terminal and an internal double bond in position 3 hindering the necessary conformation for RCM, which seems to have a strong effect on the reactivity and favours the polymerization via acyclic diene metathesis with respect to the ring closing metathesis process.
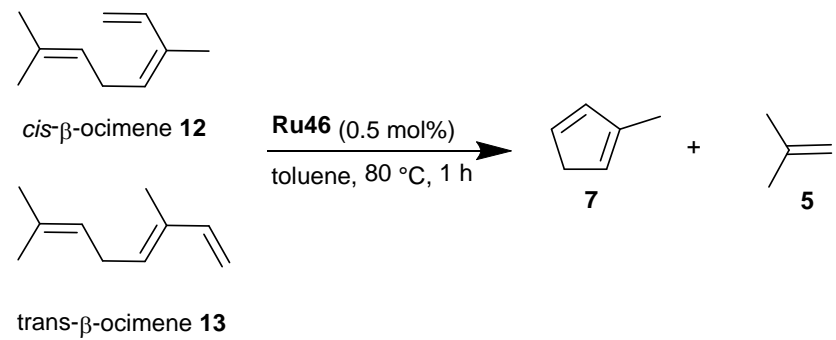

Scheme 11. RCM of cis- and trans- $\beta$-ocimene in the presence of Ru46 as catalyst

\section{Cross Metathesis (CM)}

Olefin cross metathesis is a very practical method to introduce functional groups on a hydrocarbon skeleton and to generate higher internal olefins from simple alkenes. The interest of olefin 
metathesis for the transformations of terpenoid derivatives into industrially valuable products has been emphasized in a patent. ${ }^{27}$ However, although general trends for selective cross metathesis reactions have been proposed, ${ }^{28}$ there are not many examples based on terpene derivatives. Three major types of carbon-carbon double bonds are encountered in terpenes: i) monosubstituted terminal double bonds, ii) trisubstituted double bonds featuring two methyl groups in a 2-methylprop-1-en-1-yl (prenyl) arrangement, and iii) internal endocyclic double bonds. According to the classification described in reference 28 , the first ones belong to type I olefins and are subject to fast self metathesis but also to cross metathesis with olefins of other types. The second ones are olefins of type III with no possibility of self metathesis but prone to react with olefins of type II such as electron deficient olefins. As far as internal endocyclic double bonds are concerned, they are potential substrates for ring opening metathesis polymerization and copolymerization, and eventually ring opening/cross metathesis sequences.

\subsection{Cross metathesis of terpenes with electron deficient olefins}

The second generation Hoveyda catalysts have been found to be the most efficient catalysts for cross metathesis of terpenes and terpenoids with acrylic substrates. We have successfully achieved the cross metathesis of methyl acrylate $\mathbf{1 1}$ with the monoterpenes citronellal 14, citronellol 16 and citral 18 in the presence of catalytic amounts of Ru6 (0.5 - 2 mol\%) in the green solvent dimethyl carbonate (DMC) at $60-80{ }^{\circ} \mathrm{C}$ leading to the cross metathesis products isolated in $42-70 \%$ yield (Scheme 12 ). ${ }^{29}$ As expected with methyl acrylate as cross metathesis partner, the resulting double bond presented an E-configuration, exclusively. Methyl (E)-6methyl-8-oxo-2-octenoate $\mathbf{1 5}$ has also been obtained in $40 \%$ yield upon cross metathesis of 11 (10 equiv.) and 14 using 2 mol\% of Ru4 as catalyst in refluxing dichloromethane for $1 \mathrm{~h}^{30}$ Glycerol has also been used as a green solvent for the cross metathesis of citral, linalool and geraniol. In the presence of 2 equiv. of methyl acrylate and 2 mol\% of catalyst Ru6, full conversions of these terpenoids were obtained at $60-80{ }^{\circ} \mathrm{C}$ within $15 \mathrm{~h}$, but the isolated yields of the expected products from geraniol and citral were modest (below $45 \%) .{ }^{31}$ In the case of linalool the terminal and prenyl double bonds were involved in the cross metathesis process leading to the formation of the 1,9-diester 20 with two $(E)$-double bonds in $40 \%$ yield obtained with only 0.5 mol\% of catalyst Ru6 (Scheme 12). 


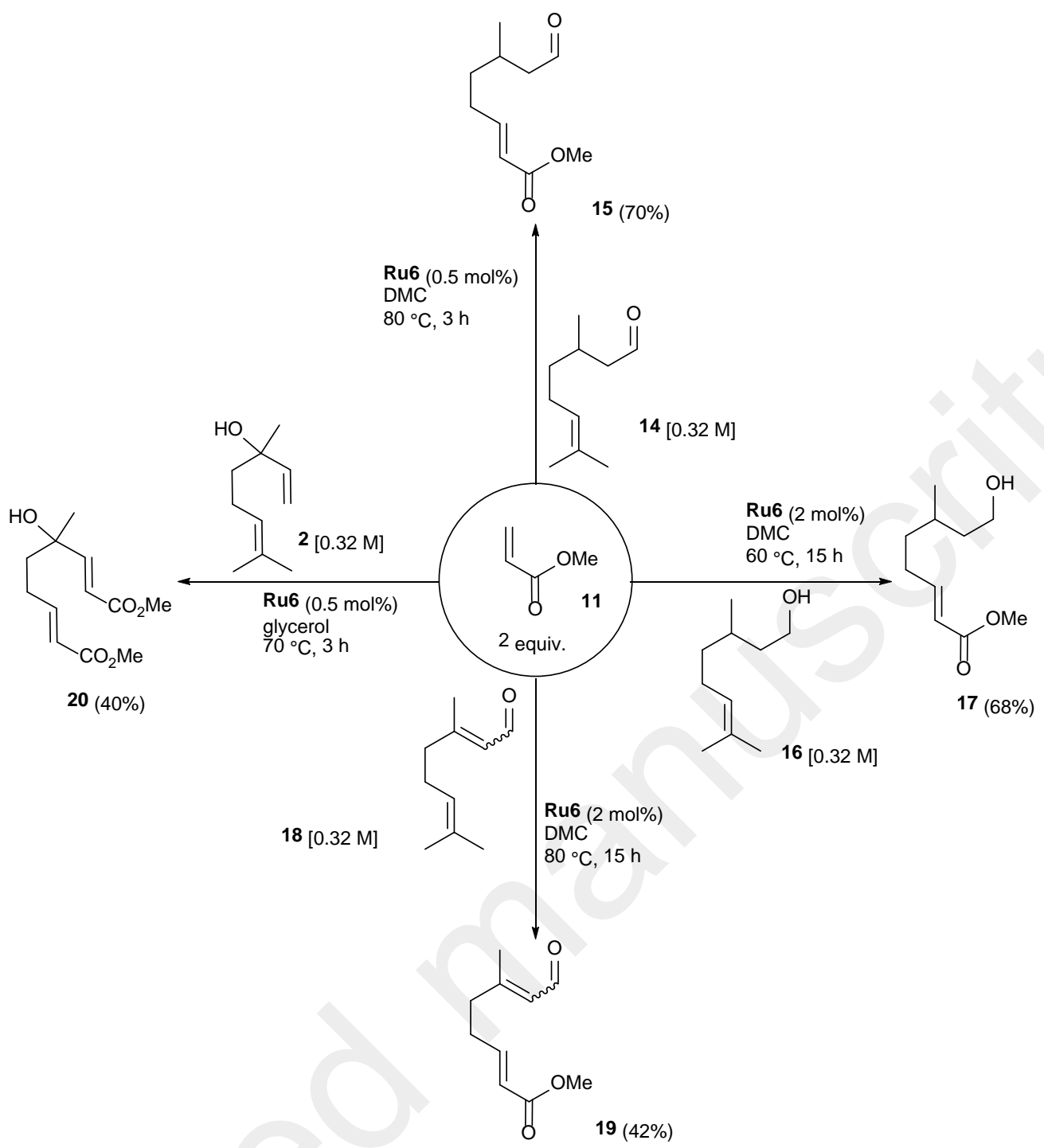

Scheme 12 Cross metathesis of terpenoids with methyl acrylate

Cross metathesis of the more sterically hindered methyl methacrylate $\mathbf{2 1}$ required more demanding conditions in terms of solvents and temperature. We found that the best conditions for the transformation of $\mathbf{1 4 , 1 6}$ and 18 were obtained under neat conditions at $80-90{ }^{\circ} \mathrm{C}$ with 2 mol\% of catalyst Ru6 (Scheme 13). ${ }^{29}$ In these conditions polymerization of methyl methacrylate occurred, which made the isolation of the metathesis products more difficult. Again, the reaction was stereoselective and only the $(E)$-isomers $\mathbf{2 2}$,
23, 24 were isolated in 75, 70 and $40 \%$ yield, respectively. These products formally correspond to new terpenoids with an oxidized prenyl group obtained without oxidation steps. These reactions constitute a clear example of green catalysis as the new terpenoids 22, 23, 24 were obtained in one step without solvent and avoided the usual 2-3 step synthesis with oxidation steps accompanied by production of large amount of wastes. 


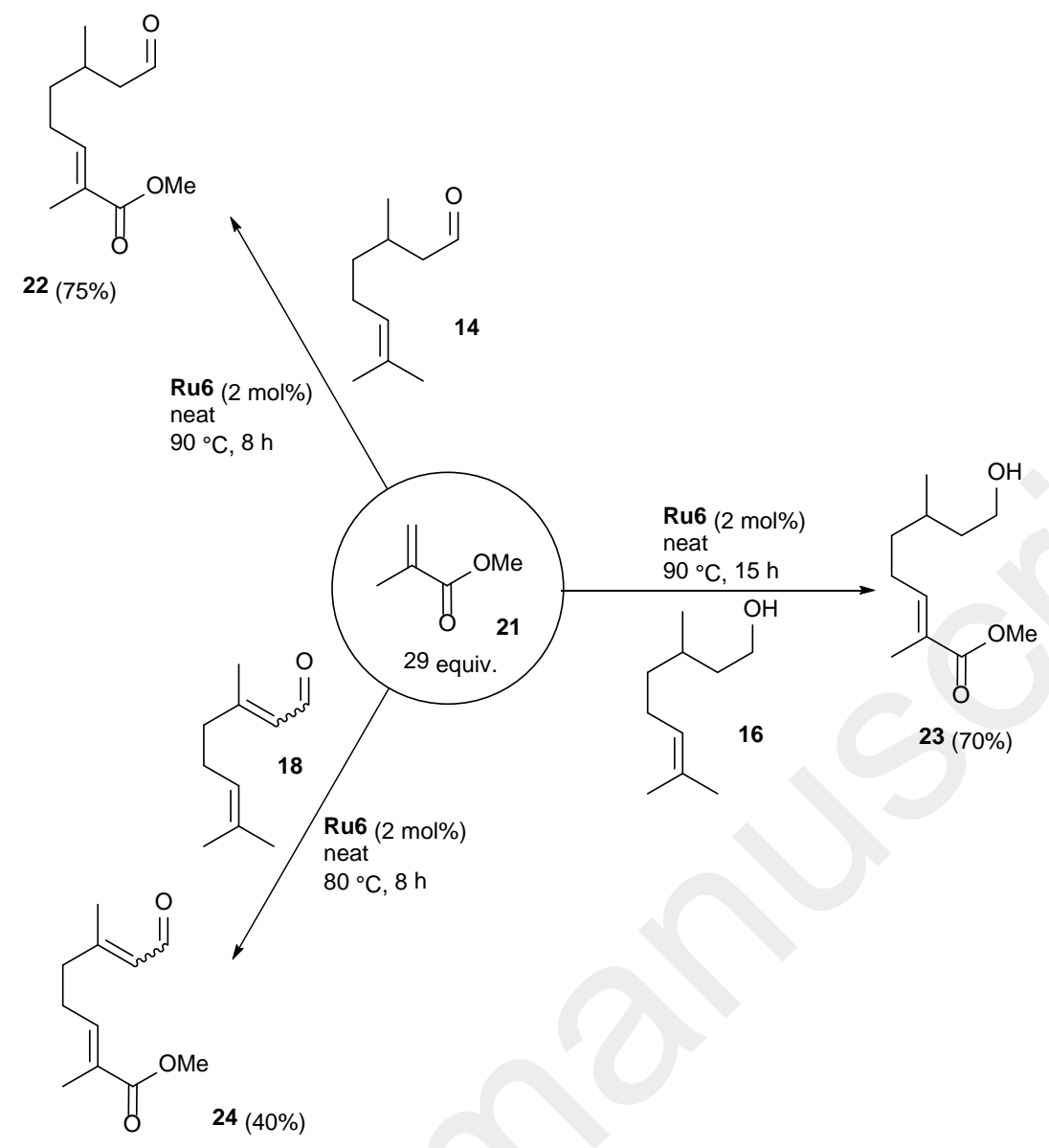

Scheme 13 Cross metathesis of terpenoids with methyl methacrylate

Cross metathesis of (S)-citronellal (S)-14 with methacrolein $\mathbf{2 5}$ was used to produce the optically pure dialdehyde $\mathbf{2 6}$ as the first step of generation Grubbs catalyst Ru4 in $\mathrm{CH}_{2} \mathrm{Cl}_{2}$ at $50{ }^{\circ} \mathrm{C}$ for $24 \mathrm{~h}$ (Scheme the synthesis of the biologically active (-)-fusarisetin A. ${ }^{32}$ The 14).

reaction was achieved in $75 \%$ yield with $5 \mathrm{~mol} \%$ of the second

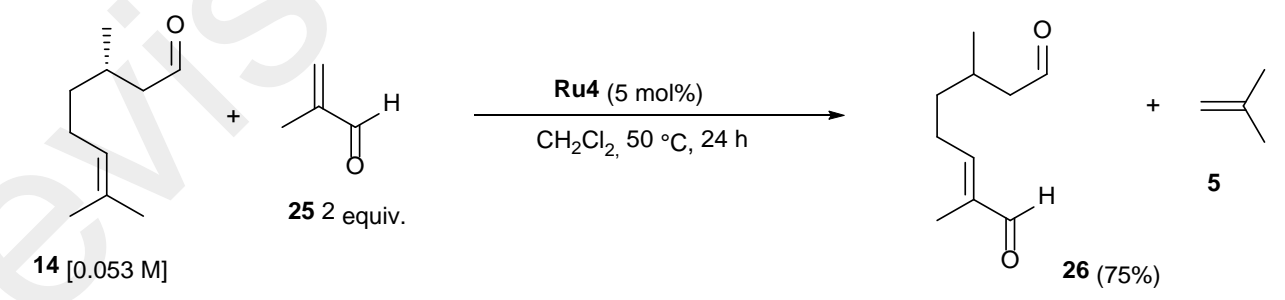

Scheme 14 Cross metathesis of (S)-citronellal with methacrolein 


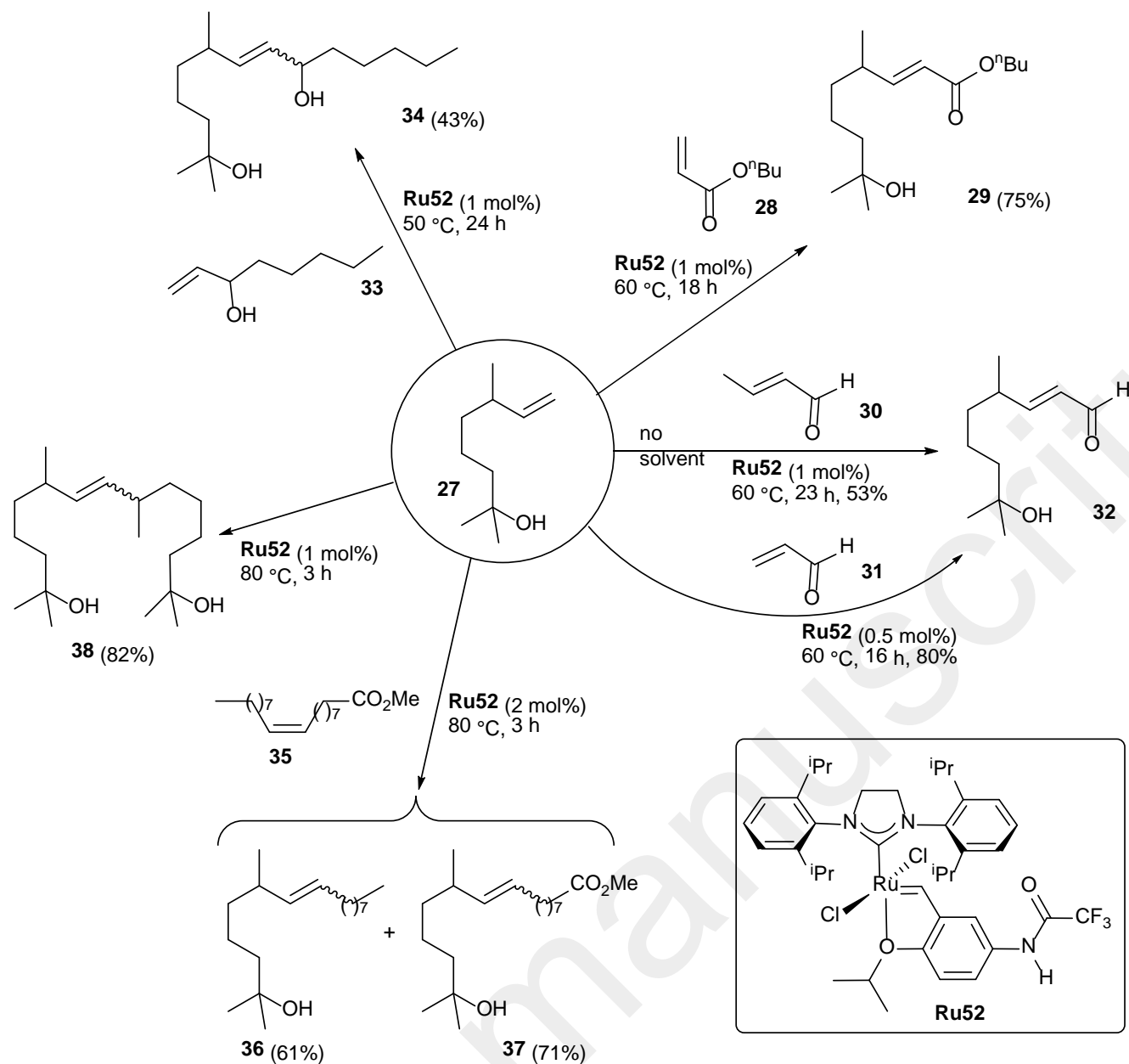

Scheme 15 Cross metathesis of dihydromyrcenol with various olefins

Dihydromyrcenol $\mathbf{2 7}$ is a monoterpene derivative featuring only one terminal double bond that has been used in cross metathesis with various partners. ${ }^{33}$ In the presence of $1 \mathrm{~mol} \%$ of the ruthenium catalyst Ru52 (Scheme 15), $n$-butyl acrylate 28 provided the $(E)$-isomer 29 after $18 \mathrm{~h}$ at $60{ }^{\circ} \mathrm{C}$ without solvent. Lower catalyst loading $(0.2,0.5 \mathrm{~mol} \%)$ were detrimental to the productivity of the reaction. With the same catalyst Ru52, cross metathesis performed at $60{ }^{\circ} \mathrm{C}$ with crotonaldehyde $\mathbf{3 0}$ and acrolein $\mathbf{3 1}$ gave the same product, namely $(E)-8$-hydroxy-4,8, dimethylnon-2-enal 32, with high stereoselectivity ( $E / Z=95: 5$ and 94:6, respectively). Acrolein $\mathbf{3 1}$ was more reactive than crotonaldehyde $\mathbf{3 0}$ as a lower catalyst loading of 0.5 mol\% gave 32 in $80 \%$ yield after $16 \mathrm{~h}$ whereas crotonaldehyde led to $53 \%$ yield of $\mathbf{3 2}$ after $23 \mathrm{~h}$ with $1 \mathrm{~mol} \%$ of catalyst (Scheme 15).
It is interesting to note that attempts to perform cross metathesis of acrylates with hindered terminal double bonds involved in cyclic terpenes such as limonene $\mathbf{4 3}$ or $\beta$-pinene $\mathbf{4 4}$ have failed and only the self metathesis product of the acrylate $\mathbf{4 5}$ was obtained (Scheme 16). ${ }^{33}$ On the other hand, it is quite surprising since the cross metathesis of acrylates with acyclic terpenes containing a terminal monosubstituted $(2,27$ - Schemes 12, 15) or 2,2disubstituted (40 - Scheme 16) double bond or a prenyl non terminal double bond $(\mathbf{1 4}, \mathbf{1 6}, \mathbf{1 8}, 39$ - Schemes 12, 13, 14, 16) have been carried out successfully with second generation Hoveyda catalysts. 


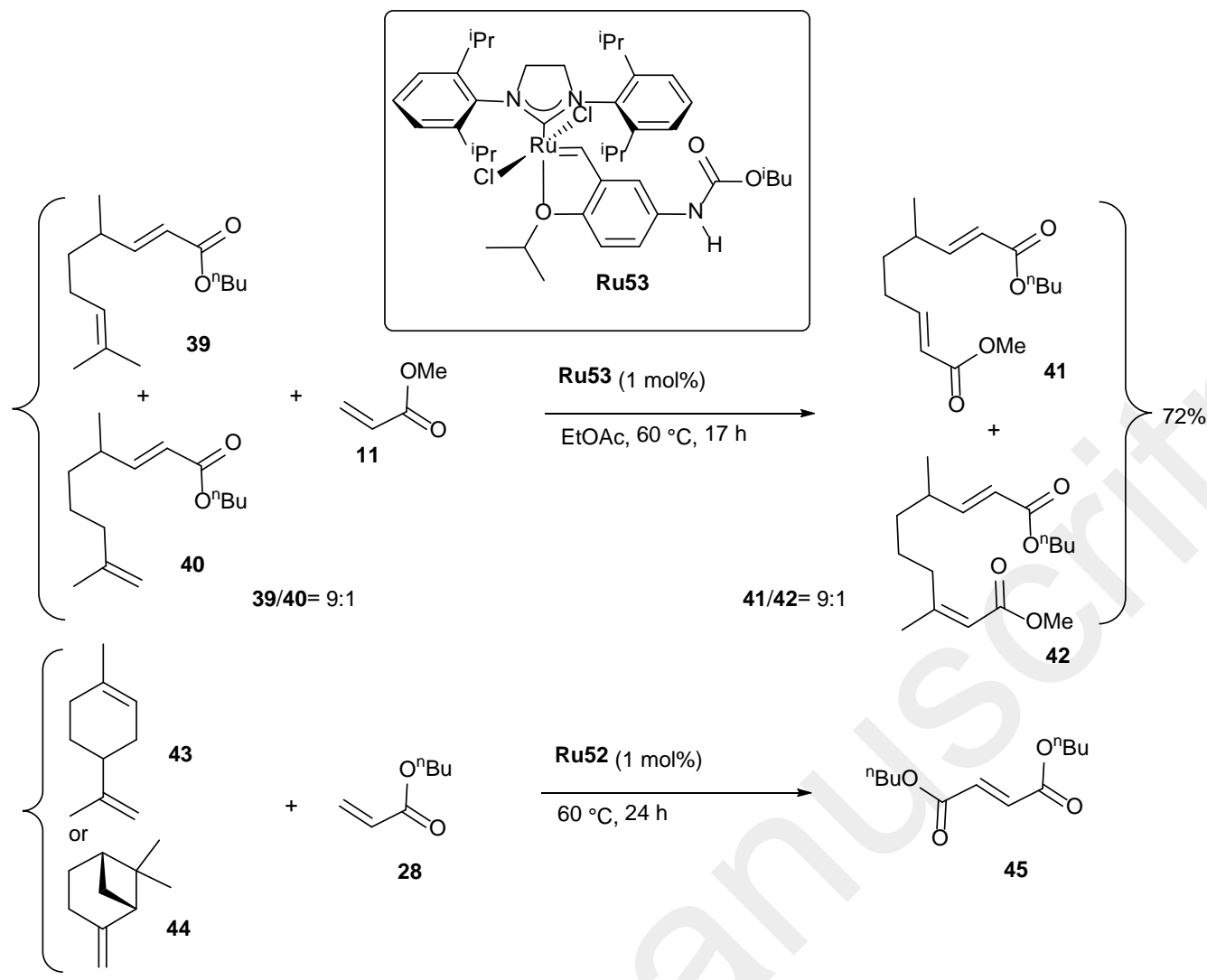

Scheme 16 Cross metathesis of acrylate with various types of acyclic double bonds

\subsection{Cross metathesis of acyclic terpenes with terminal and internal} olefins

Terminal olefins of type $1^{28}$ such as dihydromyrcenol $\mathbf{2 7}$ are known to be prone to self metathesis. Indeed, this is verified by the formation of a mixture of stereoisomers of $\mathbf{3 8}$ in $82 \%$ yield when dihydromyrcenol 27 was treated at $80{ }^{\circ} \mathrm{C}$ for $3 \mathrm{~h}$ with $1 \mathrm{~mol} \%$ of catalyst Ru52 under neat conditions (Scheme 15). ${ }^{33}$ When the terminal allylic alcohol 33 (Matsutake alcohol) was used as cross metathesis partner, $43 \%$ of $\mathbf{3 4}$ was obtained after $24 \mathrm{~h}$ at $50{ }^{\circ} \mathrm{C}$. Much better results were obtained with the internal cis double bond of methyl oleate 35. The two products corresponding to the reaction of $\mathbf{2 7}$ with each side of the double bond of $\mathbf{3 5}$ were isolated in $61 \%$ (36) and $71 \%$ (37) yields (Scheme 15). In this case, the $(E)$-stereoisomers are the major ones $(E / Z=86: 14$ and $87: 13)$ but as expected in a much less pronounced selectivity than with the acrylic electron deficient olefins 11, 21, 25, 28, 30, 31.

In order to prepare dienes from bio-resources using a rutheniumcatalyzed dehydrohalogenation reaction, we prepared the allylic chloride $\mathbf{4 7}$ by cross metathesis of citronellal $\mathbf{1 4}$ with allyl chloride 47 (Scheme 17). ${ }^{34}$ The reaction was performed in refluxing dichloromethane for $5 \mathrm{~h}$ in the presence of $2 \mathrm{~mol} \%$ of catalyst Ru54 with a 6-fold excess of $\mathbf{4 6}$, and $\mathbf{4 7}$ was isolated in $65 \%$ yield with a $E / Z$ ratio of $8.5: 1$. The latter can be easily converted into a terminal diene by elimination $\mathrm{HCl}$ catalyzed by $\left[\mathrm{Cp} * \mathrm{Ru}(\mathrm{MeCN})_{3}\right]\left[\mathrm{PF}_{6}\right]$. 
<smiles>CC(C)=CCCC(C)CC=O</smiles><smiles>C=CCCl</smiles>
466 equiv.

$14[0.35 \mathrm{M}]$
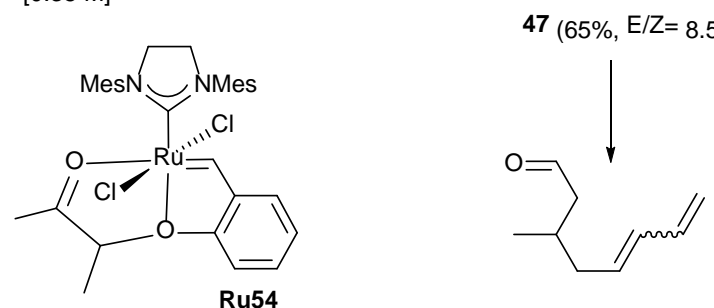

Scheme 17 Cross metathesis of citronellal 14 with allylchloride

The ruthenium complexes Ru55-Ru58 featuring 4-NMe $\mathrm{N}_{2}$-substituted and 4,5-( $\left.\mathrm{NMe}_{2}\right)_{2}$-disubstituted imidazolylidene carbene ligands were evaluated in the cross metathesis of citronellol benzyl ether 48 with cis-1,4-diacetoxybut-2-ene 49 containing an internal double bond. Under the conditions reported in Scheme 18, the catalysts bearing the non-chelated ruthenium benzylidene moiety showed much better reactivity leading to $\mathbf{7 7}$ and $85 \%$ yield of $\mathbf{5 0}$ with Ru55 and Ru56, respectively. ${ }^{35}$<smiles>CC(C)=CCCC(C)CCOc1ccccc1</smiles><smiles>CC(=O)OC/C=C\COC(C)=O</smiles>
49<smiles></smiles><smiles>CC(C)Oc1ccccc1C(Cl)(Cl)c1nc(N(C)C)cn1C</smiles>

Scheme 18 Cross metathesis of citronellol benzyl ether $\mathbf{4 8}$ with cis-1,4-diacetoxybut-2-ene 49

\subsection{Cross metathesis of cyclic terpenes}

Cyclic terpenes are more sterically hindered than the acyclic ones, and the access to the reactive catalytic center might be difficult in some cases. For instance, the lack of reactivity of limonene and $\beta$-pinene with $n$-butyl acrylate has been shown (Scheme 16). ${ }^{33}$ However, with the non-functional terminal olefin 1-hexene 53, limonene reacted in the presence of $2 \mathrm{~mol} \%$ of Ru 4 at $55{ }^{\circ} \mathrm{C}$ without solvent to give the cross metathesis product $\mathbf{5 4}$ in $40 \%$ yield (Scheme 19). ${ }^{36}$<smiles>C=C(C)[C@H]1CC=C(C)CC1</smiles>

$4318.5 \mathrm{mmol}$

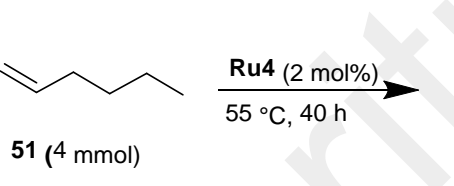

$52(40 \%)$<smiles>CCCCC=C(C)C</smiles>

Scheme 19 Cross metathesis of $(D)$-limonene with 1-hexene

This reactivity of limonene with a terminal olefin has been extended to the production of co-oligomers with 1,5-hexadiene in the presence of Ru4 (1 mol\% with respect to the diene) in an excess of limonene as solvent (30 equiv.) at $45^{\circ} \mathrm{C}$. Polyhexadiene was formed together with hexadiene oligomers featuring one or two limonene ends, the proportions of which depended on the 1,5-hexadiene concentration. $^{36}$

It has been shown that cross metathesis of the exocyclic double bond of methylenecyclohexane $\mathbf{5 3}$ with the terminal double bond of 5-acetoxy-1-pentene could be achieved efficiently in refluxing dichloromethane for $24 \mathrm{~h}$ with various second generation catalysts such as Ru6, Ru13 and their analog equipped with a 1,6-diisopropylphenylimidazolinylidene carbene Ru59 with a catalyst loading of $5 \mathrm{~mol} \%{ }^{37}$ However, the strong influence of the steric hindrance introduced by a benzyl substituent close to the double bond of methylenecyclohexane in $\mathbf{5 4}$ was obvious with a drastic decrease of the yields in $\mathbf{5 5 b}$ as compared to $\mathbf{5 5 a}$ from 78 to 17\% with Ru6, 60 to 0\% for Ru13 and 98 to 7\% for Ru59 (Scheme 20).$^{37}$ The same absence of reactivity of 2-benzyl-1methylenecyclohexane 54 was observed with Ru6 $\left(5\right.$ mol\%, $100{ }^{\circ} \mathrm{C}$ in benzene) when protected allylglycine $\mathbf{5 6}$ was used as cross metathesis partner. ${ }^{38}$ However, it was possible to produce $\mathbf{5 8}$ from the bulky cyclohexane derivative by replacing the terminal double bond of the allyl group of $\mathbf{5 6}$ by the geminal dimethyl analogue in prenylglycine 57. Using a large excess of 54 (30 equiv.), the cross 
<smiles>[R]C1CCCCC1=C</smiles>

$\mathrm{R}=\mathrm{H}, 53 ; \mathrm{Bn} 54$<smiles>C=CCCCCOC(C)=O</smiles>

\section{4}

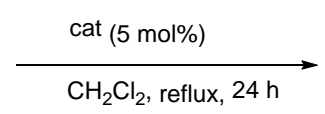<smiles>[R]C1CCCCC1=CCCCOC(C)=O</smiles>

$\mathrm{R}=\mathrm{H}$ 55a; Bn 55b

55a: Ru6 78\%; Ru13 60\%; Ru59 98\% 55b: Ru6 17\%; Ru13 0\%; Ru59 7\%

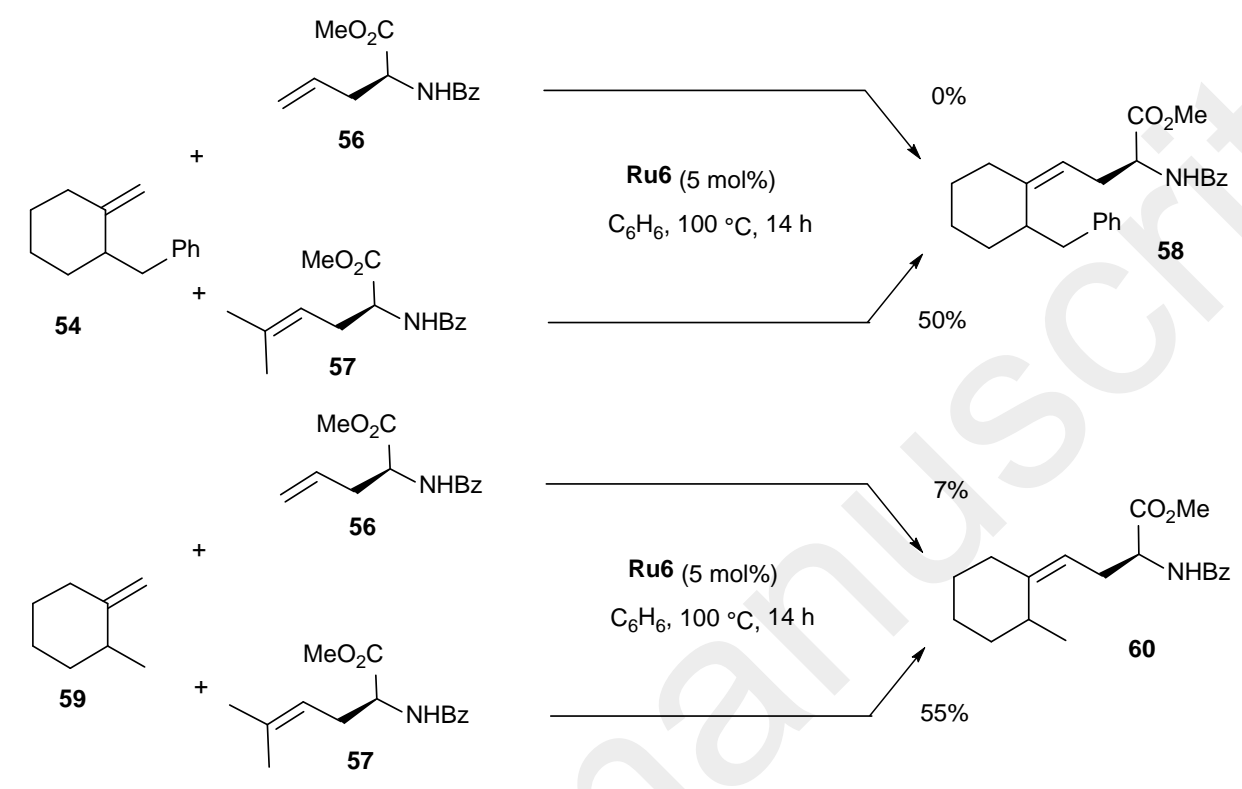

Scheme $\mathbf{2 0}$ Influence of steric hindrance on cross metathesis efficiency

Gratifyingly, this strategy was applied with success for the cross metathesis of bulky terpenes featuring a methylene substituent of a bicyclic structure. Indeed, $\beta$-pinene $\mathbf{4 4}$ and camphene 54 reacted with prenylglycine $\mathbf{5 7}$ in the presence of catalyst Ru6 to give the cross metathesis products 61 and 62 as mixtures of $E$ - and Zisomers in 36 and $34 \%$ yield, respectively (Scheme 21 ). ${ }^{38}$ Again, with these terpenes, the reaction with the allylglycine partner $\mathbf{5 6}$ failed. The cross metathesis with the aliphatic internal olefin (Z)-3methylpent-2-ene with $\beta$-pinene has been carried out with $5 \mathrm{~mol} \%$ of catalyst Ru4 at $45^{\circ} \mathrm{C}$ without solvent and the two possible cross metathesis products 64 and 65 have been observed (Scheme 21). ${ }^{39}$ The general idea to make these cross metathesis reactions with bulky double bonds successful was to favour the productive pathway with respect to the non-productive one by playing on the steric parameters of the cross metathesis partner e. g. on increasing the substitution pattern of the double bond. In this respect, the cross metathesis of $\beta$-pinene appeared to be more efficient with a trisubstituted internal olefin as cross metathesis partner (Scheme 21). This is in line with the computational studies, which indicated that non-productive metathesis of $\beta$-pinene in the presence of another olefin takes place in the presence of second generation ruthenium catalysts via formation of a carbene involving the pinene substrate, and that its self metathesis does not occur because it is inhibited both by kinetic and thermodynamic factors. ${ }^{7}$ 


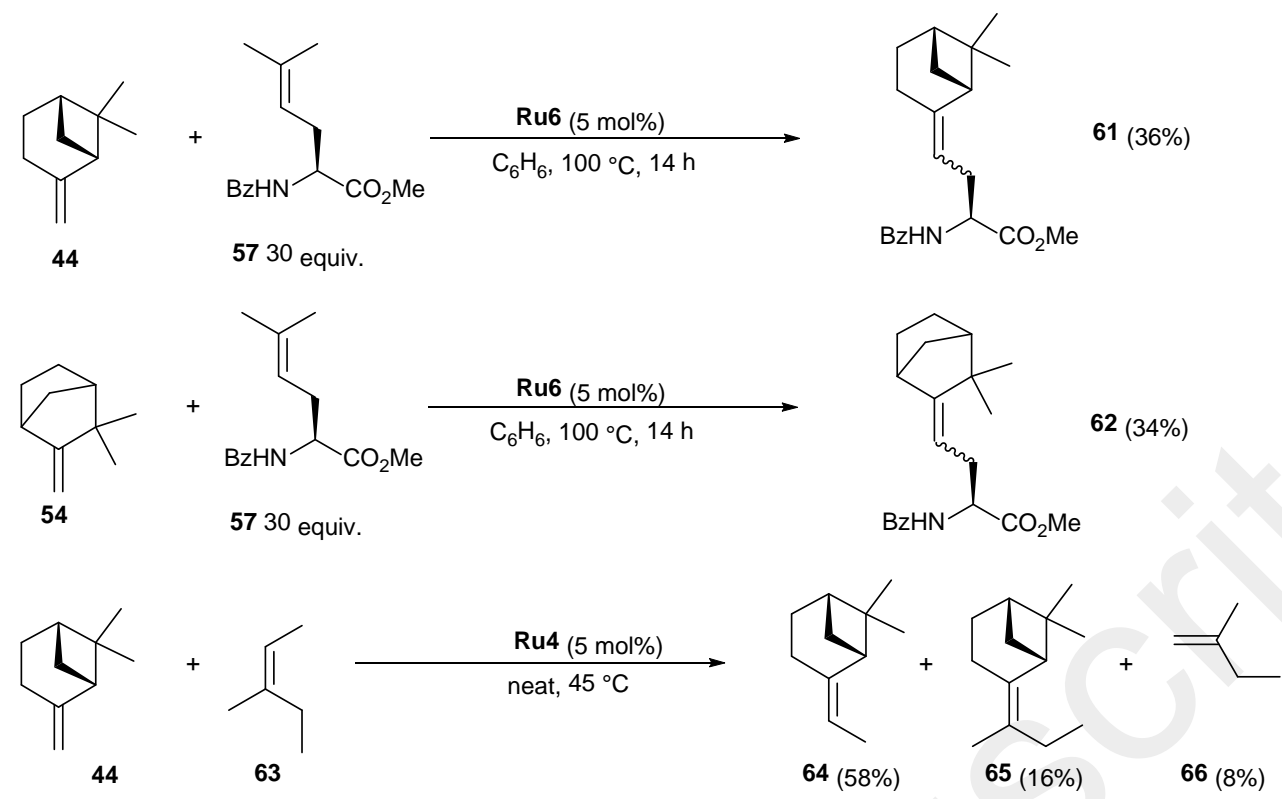

Scheme 21 Cross metathesis involving $\beta$-pinene $\mathbf{4 4}$ and camphene 54

\subsection{Cross metathesis with ethylene: ethenolysis for terpene} scission

Productive ethenolysis takes place between an internal olefin and ethylene and leads to the cleavage of the internal double bond to give two terminal olefins. This simple cross metathesis reaction has found applications for the scission of long chain unsaturated molecules and polymers, and has made possible the preparation of dienes from cyclic alkenes. In particular, it has recently found useful applications in the field of natural products transformations. ${ }^{40,41}$ Ethenolysis of the squalene 67 , the $\mathrm{C}_{30} \mathrm{H}_{50}$ triterpene containing six isoprene units has been carried out with ruthenium indenylidene complexes equipped with two different NHC carbenes (Scheme $22)^{42}$ 


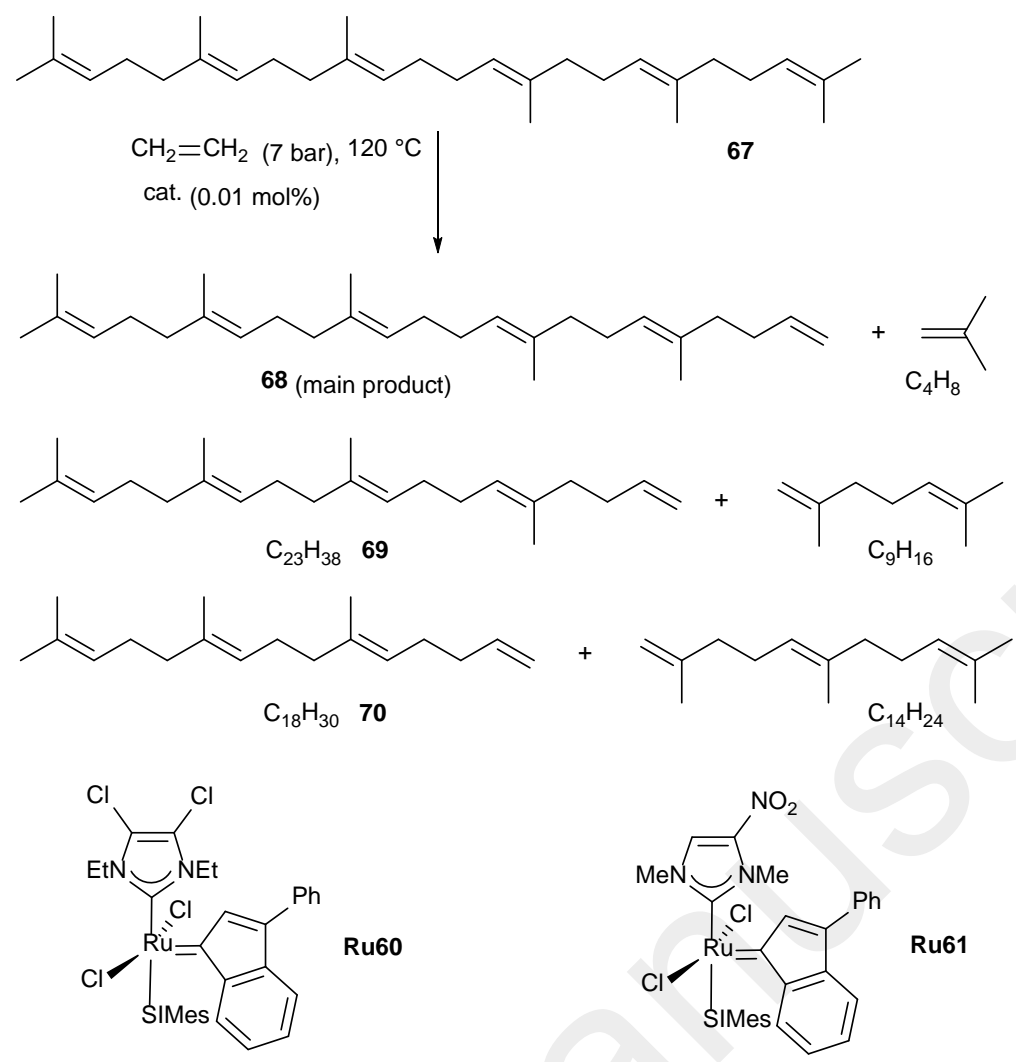

Scheme 22. Primary ethenolysis products from squalene

The ruthenium complexes Ru60 and Ru61 used at 0.01 mol\% loading were the most efficient catalysts for the cleavage of the trisubstituted double bonds of these substrates under 7 bar of ethylene in toluene at $120{ }^{\circ} \mathrm{C}$. The high amount of $\mathrm{C}_{28} \mathrm{H}_{46} 68$ as compared to $\mathrm{C}_{23} \mathrm{H}_{38} 69$ and $\mathrm{C}_{18} \mathrm{H}_{30} 70$ indicated that ethenolysis preferably occurred at the external double bonds rather than in the core of the molecule (Scheme 22). ${ }^{42}$

$\beta$-Carotene $\mathbf{7 1}$ is a tetraterpene based on two cyclohexenyl rings connected by a C18 chain composed of 9 conjugated trans carboncarbon double bonds that contains alternating 1,1,2-trisubstituted and 1,2-disubstituted double bonds. Some double bond cleavage were observed when Ru6 was used as catalyst in toluene under bubbling ethylene at room temperature. ${ }^{43}$ The first cleavage provided the tetraene $\mathbf{7 2}$, whereas the triene $\mathbf{7 3}$ and the hexaene 74 were formed only after one hour of reaction (Scheme 23). It is noteworthy that the first scission did not involve the most accessible central trans 1,2-disubstituted double bond.

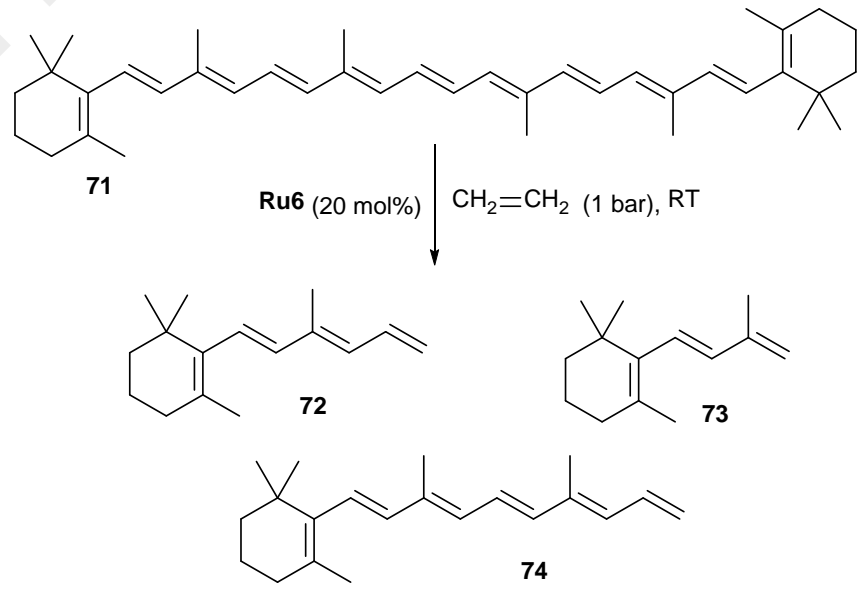

Scheme 23. Ethenolysis of $\beta$-carotene 71

The selective scission of carbon-carbon double bonds by crossmetathesis with short alkenes has been advantageously used to degrade elastomers such as polyisoprene natural rubber, and synthetic polyolefins including polyisoprene and copolymers into shorter polymers and small molecules with various catalysts based on molybdenum, tungsten and ruthenium. ${ }^{44,45}$ Initially tungsten salts associated with $\mathrm{AlCl}_{2} \mathrm{Et}$ were used for the degradation of 
polyisoprene and natural rubber by self metathesis in the absence of an external olefin, ${ }^{46}$ and the second generation Ru4 catalyst was used for the degradation of polyisoprene-polystyrene-polyisoprene block polymers. ${ }^{47}$ Then, treatment of poly-trans-isoprene and a polystyrene/polybutadiene diblock copolymer, under 1-6 bar ethylene pressure in the presence of the well-defined $\left(\mathrm{Me}\left(\mathrm{F}_{3} \mathrm{C}\right)_{2} \mathrm{CO}\right){ }_{2} \mathrm{~W}\left(=\mathrm{N}\left(2,6-{ }^{i} \mathrm{Pr}_{2} \mathrm{C}_{6} \mathrm{H}_{3}\right)\right)\left(=\mathrm{CHCMe}_{2} \mathrm{Ph}\right)$ catalyst $\mathbf{W} \mathbf{2}$ yielded low molecular weight oligomers and small amounts of $\alpha, \omega$-alkadienes. ${ }^{48}$ Degradation of trans-1,4-polyisoprene under ethenolysis conditions has also been performed with ruthenium catalyst. ${ }^{39,49}$ For instance, ethenolysis of trans-1,4-polyisoprene was very fast with the ruthenium catalyst Ru4, which depolymerized a polymer with high molar mass of $400000 \mathrm{~g} / \mathrm{mol}$ into oligomers of low molar mass of $500 \mathrm{~g} / \mathrm{mol}$ after $2 \mathrm{~h}$ at $60^{\circ} \mathrm{C}$ in toluene with a (isoprene units)/catalyst ratio of $200 .^{50}$ Catalysts Ru60 and Ru61 (Scheme 22) were also efficient for depolymerization of natural rubber in the presence of ethylene with a catalyst loading of 0.1 mol\% per double bond. ${ }^{42}$ Catalyst Ru60 as well as Ru6 have been successfully employed for ethenolysis of end-of-life tire granulates leading to about 50 weight\% of the substrates converted into organic soluble products. ${ }^{51}$

Depolymerization of cross-linked styrene-isoprene copolymers by ethenolysis was investigated in the presence of $\left(\mathrm{Me}\left(\mathrm{F}_{3} \mathrm{C}\right)_{2} \mathrm{CO}\right)_{2} \mathrm{Mo}\left(=\mathrm{N}\left(2,6-{ }^{i} \mathrm{Pr}_{2} \mathrm{C}_{6} \mathrm{H}_{3}\right)\right)\left(=\mathrm{CHCMe}_{2} \mathrm{Ph}\right)$ Mo1, Ru3 and Ru4. Under low pressure of ethylene at $20{ }^{\circ} \mathrm{C}$, catalyst Ru4 made possible the scission of the trisubstituted double bonds of crosslinked polyisoprene to form soluble oligomers in short reaction times at room temperature. ${ }^{52}$

It must be noted that not only ethylene has been used for polyolefin including polyisoprene degradation but also other internal olefins in the presence of ruthenium catalysts Ru3 and Ru4. $^{53}$ Even D-limonene ${ }^{54}$ and $\beta$-pinene ${ }^{39}$ have been used in cross metathesis with polyisoprene for the synthesis of terpeneterminated oligomers (Scheme 24). A protocol involving cross metathesis with cis-1,4-diacetoxybut-2-ene / hydrogenation of natural rubber in the presence of Ru4 provided hydrogenated oligomers. $^{55}$

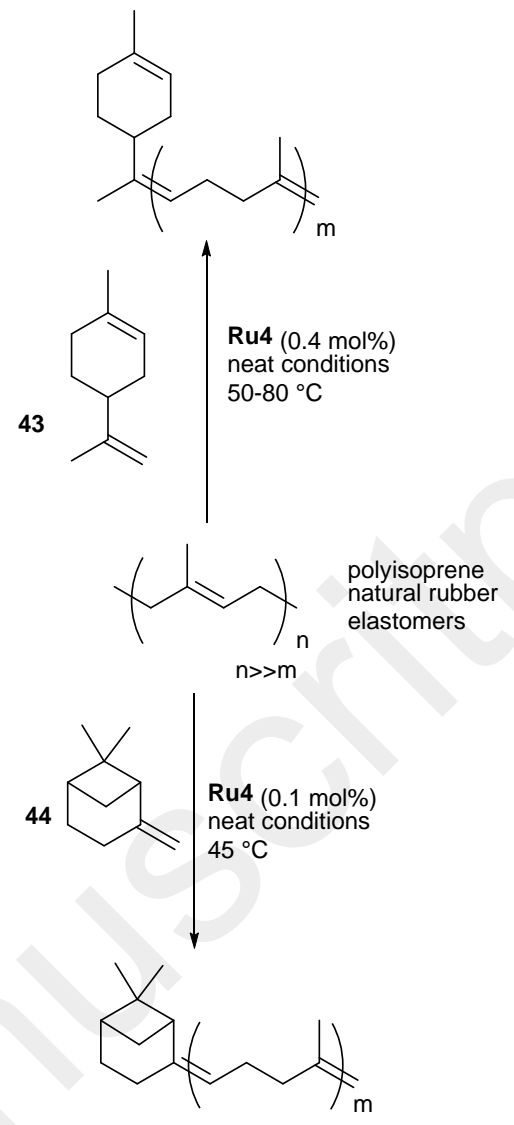

Scheme 24 Cross metathesis of polyisoprene with D-limonene $\mathbf{4 3}$ and $\beta$-pinene $\mathbf{4 4}$

Opening of the cyclohexene ring, which is a common substructure of cyclic monoterpenes, by ethylene under metathesis conditions to form 1,7- octadiene has just been reported with an heterogeneous rhenium catalyst operating under flow conditions, ${ }^{56}$ but no application to terpene is reported so far. It must be noted here that ruthenium complexes equipped with a CAAC ligand (CAAC: CycloAlkylAminoCarbene), which generate the most efficient catalysts in ethenolysis of long chain fatty acid derivatives ${ }^{57}$ have not been evaluated with terpene substrates.

\section{Ring opening metathesis polymerization}

Polymerization of strained cyclic structures under metathesis conditions is very common with norbornene derivatives, ${ }^{58}$ but has been much less studied with less strained monomers in particular with terpenes. Recently, the ring opening metathesis of the sesquiterpenes caryophyllene $\mathbf{7 5}$ and humulene $\mathbf{7 6}$ has been reported. ${ }^{59}$ The first generation ruthenium complexes Ru3 and Ru5 were inactive for this metathesis transformation and the second 
generation catalysts Ru4 and Ru62 appeared to be the most active ones (Scheme 25). Complete conversion of $\mathbf{7 5}$ was achieved even with 0.04 mol\% of Ru62 at $25{ }^{\circ} \mathrm{C}$ and its exocyclic methylene group was not involved in the polymerization process. Only trisubstituted double bonds were involved in the polymerization.<smiles>C=C1CC/C=C(/C)CC[C@@H]2[C@@H]1CC2(C)C</smiles>

75<smiles>CCCC(C)=CCCC(C)=CCC(C)(C)C</smiles>

no solvent $25^{\circ} \mathrm{C}$

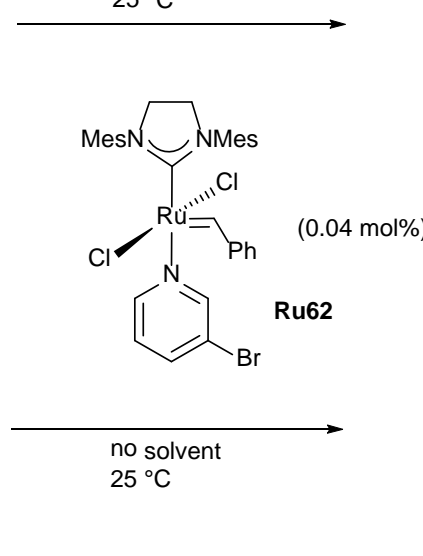<smiles>C=C(C)CCC(=C)C1CC(C)(C)[C@H]1CCC(=C)C</smiles>

77<smiles>C=CCCC(C)=CCC(C)(C)C=CCC(=C)C</smiles>

78

Scheme 25 Ring opening metathesis of two sesquiiterpenes

It can be noted that the ring opening metathesis polymerization of apopinene, exhibiting a polycyclic structure derived from $\alpha$-pinene, was successfully achieved with second and third generation benzylidene ruthenium Grubbs catalysts (Ru4, Ru6 $\left(\mathrm{RuCl}_{2}(=\mathrm{CHPh})\left(\mathrm{H}_{2} \mathrm{IMes}\right)(3-\mathrm{Br}-\mathrm{Py})_{2}\right)$ leading to a polyolefin incorporating a cyclobutane ring. ${ }^{60}$

Finally, functional hyperbranched polymers have been produced via ring opening metathesis polymerization of dicyclopentadiene in the presence of terpenes (Scheme 26). D-Limonene, limonene oxide, $\beta$-pinene, carvone have been used as chain transfer agent to modify the physical properties and thermal stability of thermosets based on polydicyclopentadiene. ${ }^{61,62}$

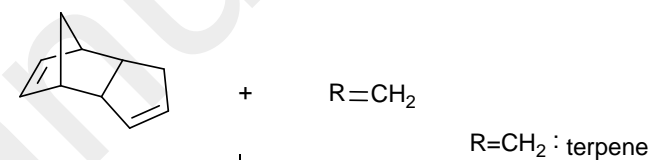

Ru4 $(0.05-0.5 \%)$

$50{ }^{\circ} \mathrm{C}, 1-20 \mathrm{~h}$

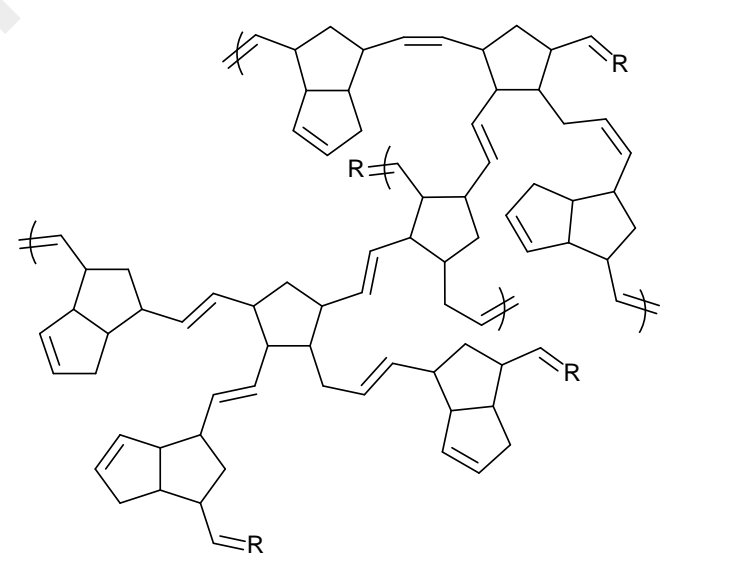

Scheme 26 Example of branched polymers obtained by ROMP of dicyclopentadiene in the presence of terpenes.

\section{Conclusion}

Transformations of terpenes by olefin metathesis processes can take place at any type of carbon-carbon double bond of these substrates. From 1,6-dienes, the ring closing metathesis easily 
affords cyclopentene derivatives as observed with citronellene, linalool, myrcene, and ocimene. This RCM reaction often competes with other metathesis reaction such as cross metathesis with functional olefins.

Terminal double bonds of acyclic terpenes are prone to cross metathesis with other olefins as well as to self metathesis.

Cross metathesis with acrylic olefins have been achieved with the monosubstituted terminal double bonds and trisubstituted prenyl double bonds of terpenes, mainly with second generation ruthenium catalysts.

Cross metathesis of bulky cyclic terpenes is more difficult and requires olefin partners favouring the productive cross metathesis versus the non-productive one.

The special case of cross metathesis with ethylene has been used for degradation of long chain polyunsaturated terpenes such as $\beta$-carotene and squalene, as well as polyisoprene and polymers containing polyisoprene blocks. It has notably been applied to the degradation of end-of-life tire granulates.

As far as ring opening metathesis polymerization is concerned, it seems that only the case of caryophyllene and humulene is reported.

It appears that terpenes have not been extensively studied in olefin metathesis transformations and that future applications have to be discovered, including couplings with other unsaturated natural resources such as fatty acid derivatives and phenylpropenoids arising from lignin.

Finally, the efficiency of olefin metathesis for the selective transformation of terpenes offers straightforward and green processes for the access to value-added products from bio-sourced substrates extracted from renewables.

\section{Conflicts of interest}

There are no conflicts to declare".

\section{Acknowledgements}

The authors acknowledge CAPES-COFECUB for support to the project $\mathrm{n}^{\circ}$ PHC 884-17 (France) and 883/2017 (Brazil); DM thanks CNPq project 422290/2016-5; ENdS thanks CNPq project 485545/2013-6. Finally, LSF thanks FAPESP 2015/26787-2 for the scholarship.

\section{References}

1. S. Zwenger and C. Basu, Biotechnol. Mol. Biol. Rev., 2008, 3 1.

2. W. Schwab, C. Fuchs and F. C. Huang, Eur. J. Lipid Sci. Technol., 2013, 115, 3.

3. K. A. D. Swift, Top. Catal., 2004, 27, 143.

4. J. L. F. Monteiro and C. O. Veloso, Top. Catal., 2004, 27, 169.

5. (a) N. Ravasio, F. Zaccheria, M. Guidotti and R. Psaro, Top. Catal., 2004, 27, 157. (b) M. Malko, A. K. Antosik, A. Wroblewska, Z. Czech, K. Wilpiszewska, P. Miadlicki and B. Michalkiewicz, Pol. J. Chem. Technol., 2018, 19, 50.

6. S. Fomine and M. A. Tlenkopatchev, J. Organomet. Chem., 2012, 701, 68

7. A. Acevedo, S. Fomine, S. Gutiérrez and M. A Tlenkopatchev, J. Organomet. Chem., 2014, 765, 17.

8. L. R. Sita, Macromolecules, 1995, 28, 656

9. W. A. Nugent, J. Feldman and J. C. Calabrese, J. Am. Chem. Soc., 1995, 117, 8992.

10. K. A. Alexander, E. A. Paulhus, G. M. L. Lazarus and N. E. Leadbeater, J. Organomet. Chem., 2016, 812, 74.

11. (a) T. Shinde, N. Zilkova, V. Hankova and H. Balcar, Catal. Today, 2012, 179, 123; (b) J. Pastva, K. Skowerski, S. J. Czarnocki, N. Zilkova, J. Cejka, Z. Bastl and H. Balcar, ACS Catal., 2014, 4, 3227.

12. T. R. Hoye and H. Zhao, Org. Lett. 1999, 1, 1123.

13. (a) D. C. Braddock and A. Matsuno, Tetrahedron Lett., 2002, 43, 3305; (b) D. C. Braddock and A. J. Wildsmith, Tetrahedron Lett., 2001, 42, 3239.

14. L. Vieille-Petit, H. Clavier, A. Linden, S. Blumentritt, S. P. Nolan and R. Dorta, Organometallics, 2010, 29, 775.

15. (a) A. Perfetto, C. Costabile, P. Longo and F. Grisi, Organometallics, 2014, 33, 2747; (b) see also C. Ambrosio, V. Paradiso, C. Costabile, V. Bertolasi, T. Carusdo and F. Grisi, Dalton Trans., 2018, 47, 6615.

16. (a) H. A. Meylemans, R. L. Quintana, B. R. Goldsmith and B. G. Harvey, ChemSusChem, 2011, 4, 465; (b) B. G. Harvey, H. A. Meylemans and R. L. Quintana, US 2015/0011807 A1, 2015.

17. D. L. I. Clive and M. P. Pham, J. Org. Chem., 2009, 74, 1685.

18. (a) J. C. Conrad, H. H. Parnas, J. L. Snelgrove and D. E. Fogg J. Am. Chem. Soc., 2005, 127, 11882; (b) J. C. Conrad, D. Amoroso, P. Czechura, G. P. A. Yap and D. E. Fogg, Organometallics, 2003, 22, 3634.

19. O. Bashir, L. Piche and J. P. Claverie, Organometallics, 2014, 33, 3695.

20. B. De Clercq and F. Verpoort, Adv. Synth. Catal., 2002, 344, 639.

21. (a) C. Bruneau and P. H. Dixneuf, Angew. Chem. Int. Ed., 2006, 45, 2176; (b) H. Katayama, H. Urushima and F. Ozawa, J. Organomet. Chem., 2000, 606, 1; (c) H. Katayama and F. Ozawa, Coord. Chem. Rev., 2004, 248, 1703.

22. T. Opstal and F. Verpoort, J. Mol. Catal. A: Chem., 2003, 200 , 49.

23. (a) A. Demonceau, A.F. Noels, E. Saive and A. J. Hubert, J. Mol. Catal., 1992, 76, 123; (b) A. W. Stumpf, E. Saive, A. Demonceau and A. F. Noels, J. Chem. Soc. Chem. Commun., 1995, 1127.

24. B. De Clercq and F. Verpoort, Tetrahedron Lett., 2001, 42, 8959.

25. S. Kobayashi, C. Lu, T. R. Hoye and M. A. Hillmyer, J. Am. Chem. Soc., 2009, 131, 7960.

26. A. Behr, L. Johnen, A. Wintzer, A. Gümüs Çetin , P. Neubert and L. Domke, Chem CatChem, 2016, 8, 515.

27. M. Mauduit, F. Caijo, C. Crévisy, US 2013/0190518 A1, 2013.

28. A. K. Chatterjee, T. L. Choi, D. P. Sanders and R. H. Grubbs, J. Am. Chem. Soc., 2003, 125, 11360.

29. H. Bilel, N. Hamdi, F. Zagrouba, C. Fischmeister and C. Bruneau, Green Chem., 2011, 13, 1448. 

Tomioka, J. Org. Chem., 2005, 70, 681.

31. A. S. Al-Ayed, Asian J. Chem., 2015, 27, 3609.

32. J. Xu, E. J. E. Caro-Diaz, L. Trzoss and E. A. Theodorakis, J. Am. Chem. Soc., 2012, 134, 5072.

33. E. Borré,T. H. Dinh, F. Caijo, C. Crévisy and M. Mauduit, Synthesis, 2011, 13, 2125

34. H. Bilel, N. Hamdi, F. Zagrouba, C. Fischmeister and C. Bruneau, Catal. Sci. Technol., 2014, 4, 2064.

35. V. César, Y. Zhang, W. Kosnik, A. Zielinski, A. A. Rajkiewicz, M. Ruamps, S. Bastin, N. Lugan, G. Lavigne and K. Grela, Chem. Eur. J., 2017, 23, 1950.

36. R. T. Mathers, K. C. McMahon, K. Damodaran, C. J. Retarides and D. J. Kelley, Macromolecules, 2006, 39, 8982.

37. I. C. Stewart, C. J. Douglas and R. H. Grubbs, Org. Lett., 2008, 10, 441.

38. Z. I. Wang, W. R. Jackson and A. J. Robinson, Org. Lett., 2013, 15, 3006

39. S. Gutiérrez and M. A. Tlenkopatchev, Polym. Bull., 2011, 66, 1029.

40. J. Bidange, C. Fischmeister and C. Bruneau, Chem. Eur. J., 2016, 22, 12226

41. J. Spekreijse, J. P. M. Sanders, J. H. Bitter and E. L. Scott, ChemSusChem, 2017, 10, 470

42. S. Wolf and H. Plenio H, Green Chem., 2011, 13, 2008.

43. I. Jermacz, J. Maj, J. W. Morzycki and A. Wojtkielewicz, Toxicol. Mech. Methods, 2008, 18, 469.

44. K. Hummel, in Olefin metathesis and polymerization catalysts, ed. Y. Imamoglu, B. Zümreoglu-Karan and A Amass, Springer Sci., Dordrecht, 1990, vol. 326, pp. 209-232.

45. K. Hummel, Pure Appl. Chem., 1982, 54, 351.

46. K. L. Sedransk, C. F. Kaminski, L. R. Hutchings and G. D. Moggridge, Polym. Degrad. Stabil., 2011, 96, 1074.

47. (a) Y. V. Korshak, M. A. Tlenkopatchev, B. A. Dolgoplosk, E. G. Adveikina and D. F. Kutepov, J. Mol. Catal., 1982, 15, 207; (b) A. Alimuniar, M. A. Yarmo ,M. Z. A. Rahman, S. Kohjiya, Y. Ikeda and S. Yamashita, Polym. Bull., 1990, 23, 119.

48. K. B. Wagener, R. D. Puts and D. W. Smith Jr, Makromol. Chem. Rapid Commun., 1991, 12, 419.

49. S. Gutierras, S. Martinez Vargas and M. A. Tlenkopatchev, Polym. Degrad. Stabil., 2004, 83, 149.

50. S. Ouardad and F. Peruch, Polym. Degrad. Stabil., 2014, 99 249.

51. S. Wolf and H. Plenio, Green Chem., 2013, 15, 315

52. S. W. Craig, J. A. Manzer and E. B. Coughlin, Macromolecules, 2001, 34, 7929.

53. (a) S. S. Solanky, I. Campistron, A. Laguerre, J. F. Pilard, Macromol. Chem. Phys., 2005, 206, 1057; (b) F. Sadaka, I. Campistron, A. Laguerre and J. F. Pilard, Polym. Degrad. Stabil., 2013, 98, 736.

54. (a) A. Martinez, S. Gutiérrez and M. A. Tlenkopatchev, Molecules, 2012, 17, 6001; (b) A. Martinez, S. Gutiérrez and M. A. Tlenkopatchev, Nat. Sci., 2013, 5, 857.

55. (a) S. Kongparakul, F. T. T. Ng and G. L. Rempel, Appl. Catal. A: Gen., 2011, 405, 129. (b) ) S. Kongparakul, F. T. T. Ng and G. L. Rempel, Top. Catal., 2012, 55, 524.

56. L. M. Kustov and D. B. Furman, J. Organomet. Chem., 2018, $867,261$.

57. (a) Y. Schrodi, T. Ung, A. Vargas, G. Mkrtumyan, T. M. Champagne, R. L. Pederson and S. Hyeok Hong, Clean, 2008 36, 669. (b) V. M. Marx, A. H. Sullivan, M. Melaimi, S. C Virgil, B. K. Keitz, D. S. Weinberger, G. Bertrand and R. H. Grubbs, Angew. Chem. Int. Ed., 2015, 54, 1919.

58. (a) A.-C. Knall and C. Slugovc, in Olefin metathesis: Theory and Practice, ed. K. Grela, John Wiley \& Sons, Hoboken, 2014, pp. 269-284. (b) G. Black, D. Maher and W. Risse, in Handbook of Metathesis,ed. Grubbs RH, Wiley, Weinheim, 2003, vol. 3, pp 2-71.
59. E. Grau and S. Mecking, Green Chem., 2013, 15, 1112

60. B. J. Strick, M. Delferro, F. M. Geiger and R. J. Thomson, ACS Sustainable Chem. Eng., 2015, 3, 1278.

61. J. M. Delancey, M. D. Cavazza, M. G. Rendos, C. J. Ulisse, S. G. Palumbo and R. T. Mathers, J. Polym. Sci. Part A: Polym. Chem., 2011, 49, 3719.

62. R. T. Mathers, K. Damodaran, M. G. Rendos and M. S. Lavrich, Macromolecules, 2009, 42, 1512. 